\title{
Financial Constraints, Institutions, and Foreign Ownership*
}

\author{
Ron Alquist ${ }^{\dagger}$ Nicolas Berman Rahul Mukherjee ${ }^{\S}$ Linda L. Tesar ${ }^{\ddagger}$
}

\begin{abstract}
We develop a model of cross-border acquisitions in which the foreign acquirer's ownership choice reflects a trade-off between easing the target's credit constraints and the costs of operating in an environment with weak institutions. Data on domestic and foreign acquisitions in emerging markets over the period 1990-2007 support the model predictions. The share of full foreign acquisitions is higher in sectors more reliant on external finance, in countries with lower financial development, and in countries with higher institutional quality. Sectoral external finance dependence accentuates the effect of country-level financial development and institutional quality. By contrast, the level of foreign ownership in partial acquisitions is insensitive to institutional factors and depends weakly on financial factors.
\end{abstract}

Keywords: Foreign direct investment; foreign ownership; mergers and acquisitions; financial development; institutional quality.

JEL Codes: F21, F23, G34, L24, L60.

*A previous version of this paper circulated under the title "Liquidity-Driven FDI". AQR Capital Management is a global investment firm, which may or may not apply similar investment techniques or methods of analysis as described herein. The views expressed here are those of the authors and not necessarily those of AQR.

${ }^{\dagger}$ AQR Capital Management. E-mail: ron.alquist@aqr.com.

${ }^{\ddagger}$ Aix-Marseille Univ., CNRS, EHESS, Centrale Marseille, AMSE, France, and CEPR. E-mail: nicolas.berman@univ-amu.fr.

${ }^{\S}$ Corresponding author: Department of Economics, Graduate Institute of International and Development Studies. Address: Maison de la Paix, Chemin Eugene Rigot 2, 1202 Genève, Switzerland. E-mail: rahul.mukherjee@graduateinstitute.ch.

`Department of Economics, University of Michigan and NBER. E-mail: ltesar@umich.edu. 


\section{Introduction}

Since the early 2000s, there has been a rapid increase in cross-border mergers and acquisitions (M\&A), and a significant share of those transactions involve purchases of firms in the developing world with most of the capital originating in developed countries (UNCTAD, 2016). Such acquisitions entail both benefits and costs for foreign acquirers based in developed countries. On the one hand, the relative scarcity of capital due to low financial development depresses the internal valuations of target firms, making the targets attractive to foreign acquirers seeking higher returns. ${ }^{1}$ On the other hand, operating firms in those markets involves sourcing local inputs in an unfamiliar environment with weaker institutions, less secure property rights, and more distortionary policies, all of which potentially raise the cost of operation. We henceforth refer to costs faced by foreign owners when trying to operate fully owned firms, i.e., without domestic co-ownership, in such an environment as "weak institutions" (North, 1991) for conciseness. We show that the choice of ownership structure in cross-border M\&A is critical in balancing these benefits and costs, and represents an endogenous response of multinational corporations to the particular operating environment they face in developing countries.

We first document a set of facts about foreign ownership of firms in emerging market economies (EMEs). Existing research has established that the extent of foreign control in FDI is an important determinant of technology transfer, labor productivity, wages, export participation, as well as the nature and extent of spillovers to local firms. Our study examines the factors that determine the extent of control. We develop a model that clarifies how the competing economic forces - the provision of capital versus the mitigation of the costs associated with weaker institutions - jointly determine the optimal degree of foreign ownership and the relative volumes of brownfield FDI investment across different countries and sectors. We find evidence that financial, institutional and technological factors all play a role in the choice between full and partial acquisitions, as well as the ownership structure in partial acquisitions.

To highlight the trade-offs facing a foreign acquirer, our model postulates that production in the emerging market requires capital and a local input. The foreign acquirer solves for an optimal ownership contract between itself and the domestic target firm that captures its advantage in having greater access to capital markets relative to the credit-constrained target, and the potential disadvantages of operating a firm in an emerging market. The foreign owner is at a disadvantage over local firms in that it faces additional costs due to weaker institutions. We model this as a markup on local inputs paid only by the foreign firm, making local production more expensive and reducing profits. The markup also adds an incentive for operating the firm with a local co-owner. Thus, the prospective foreign acquirer faces a choice between obtaining full control of the credit-constrained target, in which case it is compelled to pay a higher price for the local input, or to take partial ownership, in which case the domestic partner can provide the local input at the lower price.

Three sets of predictions emerge from the model. The first and second pertain to the ownership structure chosen by the foreign acquirer, conditional on entry. Full foreign acquisitions (relative to minority foreign ownership) of emerging market targets are more likely in sectors

\footnotetext{
${ }^{1} \mathrm{Up}$ to $46 \%$ and $34 \%$ of South Asian and Latin American firms of different sizes reported difficulties in obtaining their desired levels of credit (WBES, 2013).
} 
that have a greater dependence on external finance, and in countries that are less financially developed: At the margin, the differential payoff to the foreign firm from a full versus a partial acquisition rises with the severity of the target's credit constraint. A lower markup on the local input in the model, i.e., better institutions, tilts the ownership structure towards full foreign ownership by increasing the marginal payoff from a full acquisition. The effects of the local input price markup and financial development are also predicted to be the largest for the sectors of the economy most dependent on external finance.

The second set of predictions pertains to partial acquisitions (conditional on entry) and the local input is therefore provided by the emerging market partner. Here a trade-off arises between acquiring greater ownership and leaving the domestic owner with enough equity to motivate the optimal provision of the local input. The size of a foreign stake in a partial acquisition is larger in industries that are more dependent on external finance and in less financially developed countries, but this dependence is tempered by technological factors. Because the importance of the local input varies across industries, the optimal equity share that motivates the domestic owner to provide it optimally also varies. In industries where the domestic equity share in profits is high enough to exceed the stand-alone value of the firm (the domestic owner's outside option), the share is governed by technological factors rather than either of the two financial factors. This effect weakens the influence of finance in determining the precise size of partial stakes. At the same time, because all partial acquisitions involve local input provision by the domestic agent, the input price markup is predicted not to influence the ownership structure in partial acquisitions.

Our final predictions relate to the overall likelihood of foreign acquisitions across different countries and sectors. Foreign acquisitions are predicted to be more likely in sectors that have a greater dependence on external finance, in countries where financial markets are less developed, and when the markup paid by foreign firms for the local input is lower (i.e., when institutions are better). Lack of access to finance lowers the value of the target to the domestic owner, while a low markup on the local input increases its value for the foreign firm. Both factors thus increase profits to the foreign owner and therefore make foreign acquisition more likely.

We test these predictions in a panel of cross-border M\&A transactions by developed market firms in fourteen emerging markets over the 1990-2007 period. We use the Rajan and Zingales (1998) measure of external finance dependence and commonly used proxies for financial development as our main financial indicators. We use anti-corruption indices as our baseline measure of institutional quality to capture the comparative disadvantage that foreigners face in obtaining the local input on their own without help from a domestic co-owner. ${ }^{2}$ The regression evidence confirms the main predictions of the model. There is a positive relationship between the probability of a full foreign acquisition and dependence on external finance of a target, financial underdevelopment, and measures of institutional quality. External finance dependence is found to accentuate the latter two effects, also consistent with the model. Second, we examine the relationship between ownership structures in the subset of partial acquisitions and financial

\footnotetext{
${ }^{2}$ We conduct robustness checks using different institutional measures - an anti-corruption measure from Transparency International, an indicator of the quality of government from the International Country Risk Guide (2013), and an index of business freedom from the World Bank's Doing Business study - that most closely correspond to the spirit in which institutions are modelled theoretically. First, we test whether there is evidence in favor of the predictions regarding the likelihood of full versus partial foreign acquisitions.
} 
development, institutional quality, and the target's dependence on external finance. Consistent with the model, we find that institutional quality plays no role in ownership structure choice in partial foreign acquisitions, and uncover a weak positive relationship between the average sizes of minority foreign acquisitions and our financial indicators. Finally, we also find strong evidence consistent with the predictions of the model regarding the variation across sectors and countries in the overall probability of foreign acquisitions.

The remainder of the paper is organized as follows. We review existing research and relate it to our work in the next subsection. In Section 2 we describe some prominent features of crossborder acquisitions in the manufacturing sector of emerging markets. We then describe our theoretical model and establish some empirical hypotheses in Section 3. Section 4 reports our main empirical results while Section 5 provides robustness checks and some additional results. Section 6 concludes.

\section{$1.1 \quad$ Related research}

The focus of this paper - the determination of the optimal foreign ownership structure in crossborder M\&A - brings together several strands of research in international economics and finance. The first one is about the determinants of cross-border M\&A. It is exemplified by papers such as Aguiar and Gopinath (2005), Acharya et al. (2011) and Alquist et al. (2016) that examine how liquidity-provision by foreign firms drives so-called fire-sale FDI during financial crises in EMEs. Other research has documented that foreign acquisitions relax credit constraints in domestic targets outside of crisis periods. Wang and Wang (2015) provide evidence on the ability of cross-border M\&A to relax credit constraints in a sample of Chinese firms, while Erel et al. (2014) provide similar evidence from the European market for corporate control. ${ }^{3}$ We build on the main finding of this research - namely, that easing credit constraints is a key function of cross-border M\&A - to examine its effects on the pattern of foreign ownership. Our results provide a framework for interpreting the positive abnormal acquirer returns associated with the acquisition of controlling stakes in EME firms by developed-market firms (Chari et al., 2010).

Second, for aggregate FDI including greenfield investments, research shows how domestic frictions influence both the quantity and pattern of direct investments by foreigners. Harrison et al. (2004) find that aggregate FDI flows relax financial constraints and that capital account restrictions make them more binding. Similarly, Desbordes and Wei (2017) present evidence that both the source and destination countries' financial development affect the volumes of different types of FDI, including cross-border M\&A. The quality of institutions in the host country also matters for aggregate FDI flows and its composition. Wei (2000), for example, shows how contract enforcement influences the volume of FDI, while Davies et al. (forthcoming) find that institutional factors are relatively more important for foreign M\&A transactions than they are for greenfield FDI. ${ }^{4}$ In related work, Javorcik and Wei (2009) find that corruption

\footnotetext{
${ }^{3}$ Other non-financial drivers of the likelihood of foreign acquisitions have been documented in Erel et al. (2012). Some papers look at the role of intellectual property rights protection (Alimov and Officer, 2017) and the cross-border deployment of industry-country-specific intangible assets (Frésard et al., 2017).

${ }^{4}$ The effects of country-level financial development and external finance dependence on firm behavior have been examined in several papers. Huang et al. (2016) present evidence that Chinese firms with greater financial constraints are more likely to be acquired and controlled by foreign firms. Similarly, Bustos (2007) finds that Argentine firms in external-finance dependent industries are more likely to be foreign owned and to finance their
} 
reduces the volume of inward FDI to emerging markets and shifts the ownership structure toward joint ventures, and Kesternich and Schnitzer (2010) document the influence of political risk on multinationals' choice of capital structure in FDI projects.

While these papers treat each of the factors separately, we provide a framework to analyze the trade-off faced by foreign acquiring firms when they have a comparative advantage in providing finance and technology and yet also face institutional frictions in the destination country. In a model that builds on Asiedu and Esfahani (2001) and Alquist et al. (2016), we show that the choice of ownership structure resolves this tension and maximizes the value of the firm. ${ }^{5}$ Understanding this trade-off and its effects on foreign ownership structures yields lessons about the motives for brownfield FDI, beyond those provided by an analysis of aggregate FDI volumes and each of the drivers separately. ${ }^{6}$

This paper also relates to work on international intra-firm trade and the boundaries of multinational enterprises (MNEs). This research, which is surveyed in Antràs and Yeaple (2014), has investigated theoretically and empirically several mechanisms through which firm boundaries are extended using FDI. A non-exhaustive list of the mechanisms that have been shown to be important includes the relative location of firms along a global value chain and the elasticity of final demand (Antràs and Chor, 2013), final product prices (Alfaro et al., 2016), the relative contractibility of upstream and downstream production stages (Alfaro et al., forthcoming), and intangible assets and intellectual property rights protection (Bolatto et al., 2017). When we take the model to the data, we control for these alternative explanations of FDI. In this area of research, the paper most related to this one is Antràs et al. (2009). ${ }^{7}$ This paper, however, relies on a different mechanism - the interaction of financial constraints and local inputs - to deliver two complementary predictions: (1) the presence of local inputs makes full foreign ownership a distinctive organizational form that, at the margin, is strongly influenced by local institutions; and (2) this stands in contrast to the determinants of the size of minority stakes, which are shaped either by financial constraints or technology. While weak investor protection increases foreign equity ownership in Antràs et al. (2009), the alternative mechanism in this paper leads to

operations with funds from their parent company. Financial frictions also influence decision to export. Manova et al. (2015) show theoretically and empirically that firm-level financial frictions restrict the volume of trade: Foreign affiliates and joint ventures in China have better export performance than private domestic firms. Bilir et al. (2017) provide evidence that U.S.-based multinational corporations are more likely to open affiliates in countries with more developed financial markets and that affiliate sales in the local market decrease relative to those in the parent country and third-country destinations.

${ }^{5}$ Asiedu and Esfahani (2001) focus on the role of partner-specific inputs and infrastructure in a model of greenfield joint ventures based on Eswaran and Kotwal (1985). They solve for the amount of input provided by each agent as well as the level of government infrastructure and taxation. Since the foreigner starts a new joint venture with a domestic partner, the authors normalize the outside option of the domestic agent to zero. By contrast, the domestic agent in our model owns a going concern and hence has an outside option whose value depends on financial constraints. The outside option is central to our analysis and results. Alquist et al. (2016) analyze changes in the industry composition of foreign ownership during financial crises, and Mukherjee and Proebsting (2017) examine how the composition of the pool of domestic acquiring firms changes during financial crises. Neither of these papers addresses the optimal ownership structure problem of an individual firm.

${ }^{6}$ For example, our results show why foreign ownership structures may be insensitive to institutional factors for minority stakes while external finance matters for all levels of foreign ownership. We abstract from the choice between greenfield FDI and M\&A that Nocke and Yeaple (2007, 2008) have examined.

${ }^{7}$ Antràs et al. (2009) develop a model in which MNEs have expertise in monitoring the deployment of proprietary technologies on behalf of external investors. The expertise makes MNE co-investment in the form of FDI, as opposed to arms-length technology transfer, the optimal way to finance foreign projects in a setting of weak investor protection. Using data on U.S. MNEs they find that the share of affiliate equity owned by the parent firm is higher in countries with weak investor protection and shallow financial markets. 
lower foreign equity participation when general institutions in a country are weaker. In addition, our empirical tests use a complementary dataset on cross-border M\&A conducted by acquiring firms from a large set of advanced countries.

Finally, our results shed light on how the extent of foreign ownership affects the behavior and characteristics of domestic firms. Existing research indicates that the degree of foreign ownership rather than the presence of foreign owners per se affects the productivity of the targets, their export participation, and leads to cross-industry spillovers in the host country. ${ }^{8}$ By expanding our understanding of sector and country-specific determinants of foreign ownership shares, our evidence has implications for the distribution of gains from FDI across EMEs as well as across sectors within a given country.

\section{Stylized facts}

In this section, we present the data and document several characteristics of foreign acquisitions of manufacturing firms located in emerging markets - namely, the heterogeneity across industries and target countries in the probability of both partial and full foreign acquisitions and, within the set of partial acquisitions, the sizes of the stakes acquired. We also provide preliminary evidence relating these patterns of M\&A to sectoral external finance dependence and countryspecific financial development. These findings motivate the model we use to guide the empirical analysis. Section B.1 of the online appendix provides further information about the data and where we obtained them.

\subsection{M\&A transaction data}

The transactions data are from a sample of foreign acquisitions that occurred in fourteen emerging-market economies between 1990 and 2007. We use a subset of the data available from the Securities Data Company (SDC) Thompson's International Mergers and Acquisitions database, which reports public and private merger and acquisition transactions involving at least a 5\% ownership stake in the target company. After merging with our sector and country-level data, our final sample includes all of the domestic and foreign acquisitions that occurred over the period in manufacturing industries (SIC codes 2000-4000) in the following countries ${ }^{9}$ : Argentina, Brazil, Chile, China, India, Indonesia, Malaysia, Mexico, Peru, Philippines, South Africa, South Korea, Thailand, and Vietnam. ${ }^{10}$ For each transaction, we have information about the sectors and countries of both the target and the acquirer, the year, and the share acquired. ${ }^{11}$

\footnotetext{
${ }^{8}$ See, for example, Greenaway et al. (2014), Javorcik and Spatareanu (2008), Bircan (2017), Chhibber and Majumdar (1999), and Havránek and Iršová (2011, 2013).

${ }^{9}$ We restrict the analysis to the manufacturing sector because estimates of external finance dependence are only available for those industries. We do, however, report results on the full sample as a robustness check (see the online appendix Table A.10).

${ }^{10} \mathrm{An}$ alternative source of data for M\&A transactions is the Zephyr dataset available from Bureau Van Dijk. The SDC data set has better coverage of corporate transactions, both in terms of years covered and in terms of geographic coverage. In particular, the coverage of Zephyr for emerging market M\&A transactions is sparse until the mid-2000s. Bollaert and Delanghe (2015) discusses the distinct advantages of SDC compared with Zephyr for questions related to the pattern of foreign ownership.

${ }^{11}$ The online appendix contains more details about the SDC data. The information about the transactions is obtained from a variety of news sources, regulatory agencies, trade publications, and surveys. We exclude the period after 2007, which was characterized by the global financial crisis and significant variation in the liquidity constraints faced by acquirers based in developed markets.
} 


\section{$2.2 \quad$ Descriptive statistics}

Table 1 presents descriptive statistics of M\&A transactions in emerging markets and splits the transactions by country of origin and sector of the target. The online appendix provides additional figures that depict the transactions by year (Figure A.1) and year $\times$ target country (Table A.1), as well as by country of origin and sector of the acquirer (Table A.2 and A.3), and by fraction acquired (Table A.4).

Foreign acquisitions represent $40 \%$ of the transactions in our sample. The geographic breakdown of the acquirers is diverse, although most are based in developed countries (Table A.2): about $90 \%$ of the foreign transactions in the manufacturing sector involve an acquirer from a developed economy. Over the sample period, the United States accounts for $28 \%$ of foreign acquisitions, and Europe and Asia for about 30\% each. Table A.3 shows that foreign acquirers are generally firms in the manufacturing sector $(62 \%)$ or the finance, insurance and real estate (FIRE) sectors (25\%).

Figure 1: Distribution of fraction acquired

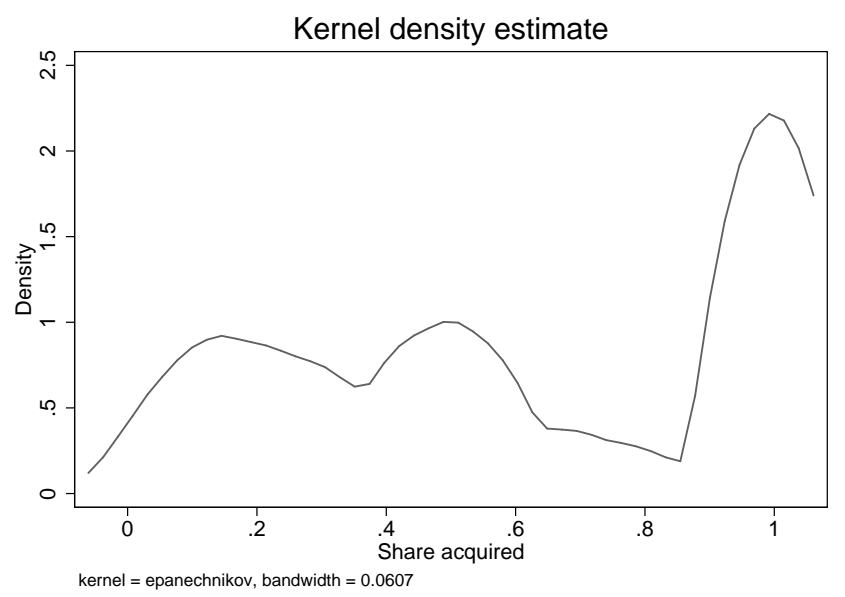

Note: This figure presents the Kernel density of the fraction acquired by foreign firms in our sample.

We are primarily interested in the role of country and sectoral characteristics of the target on cross-border M\&A. Our data suggests that there is significant heterogeneity in the location of the target and its sector of operation. Of a total of 9,919 transactions, the largest number of acquisitions occur in China, Malaysia, India, South Korea and Brazil. Over the sample period, almost $70 \%$ of acquisitions occurred in Asia and about $24 \%$ in Latin America. As shown in Table 1, however, the acquisitions in Latin America are more likely to involve a foreign acquirer (58\% of the transactions) than their Asian counterparts (35\% of foreign acquisitions). Acquisitions are more common in the food products $(15 \%)$, chemicals $(18 \%)$ and electric/electronic equipment $(12 \%)$ sectors, while foreign acquisitions are more common in the tobacco, transportation, and the measuring, analyzing and controlling instruments sectors. Foreign acquisitions account for more than $40 \%$ of the total number of acquisitions in these industries. The presence of foreign acquirers thus does not appear to be concentrated in the sectors that account for more acquisitions overall. Foreign acquisitions are the least common in the leather, wood, and furniture 
Table 1: Acquisitions by country of target

\begin{tabular}{|c|c|c|c|c|c|c|}
\hline \multirow{2}{*}{$\begin{array}{l}\text { Acquisitions } \\
\text { Full sample }\end{array}$} & & \multicolumn{2}{|c|}{$\begin{array}{c}\text { \# transactions } \\
\text { All }\end{array}$} & \multicolumn{2}{|c|}{$\begin{array}{c}\text { Share full Share acquired } \\
\text { Foreign }\end{array}$} & \multirow{2}{*}{$\begin{array}{c}\begin{array}{c}\text { Share acquired } \\
\text { Foreign \& partial }\end{array} \\
0.38\end{array}$} \\
\hline & & 9919 & 0.40 & 0.39 & 0.62 & \\
\hline Region & Country & & & & & \\
\hline \multicolumn{7}{|l|}{ Latin America } \\
\hline & Argentina & 534 & 0.61 & 0.49 & 0.70 & 0.42 \\
\hline & Brazil & 930 & 0.52 & 0.53 & 0.75 & 0.47 \\
\hline & Chile & 186 & 0.61 & 0.40 & 0.63 & 0.38 \\
\hline & Mexico & 637 & 0.64 & 0.57 & 0.75 & 0.42 \\
\hline & Peru & 94 & 0.48 & 0.33 & 0.65 & 0.48 \\
\hline & Total & 2381 & 0.58 & 0.52 & 0.73 & 0.43 \\
\hline \multicolumn{7}{|l|}{ Asia } \\
\hline & China & 2443 & 0.43 & 0.32 & 0.59 & 0.39 \\
\hline & India & 955 & 0.31 & 0.19 & 0.39 & 0.24 \\
\hline & Indonesia & 270 & 0.57 & 0.18 & 0.48 & 0.37 \\
\hline & Korea. Rep. & 948 & 0.29 & 0.39 & 0.61 & 0.37 \\
\hline & Malaysia & 1449 & 0.16 & 0.37 & 0.60 & 0.36 \\
\hline & Philippines & 192 & 0.48 & 0.23 & 0.52 & 0.39 \\
\hline & Thailand & 505 & 0.44 & 0.19 & 0.47 & 0.34 \\
\hline & Vietnam & 67 & 0.69 & 0.22 & 0.55 & 0.43 \\
\hline & Total & 6823 & 0.35 & 0.29 & 0.54 & 0.36 \\
\hline South Africa & & 715 & 0.32 & 0.60 & 0.77 & 0.41 \\
\hline
\end{tabular}

\begin{tabular}{|c|c|c|c|c|c|c|}
\hline \multirow[t]{21}{*}{ SIC } & \multicolumn{6}{|l|}{ Industry } \\
\hline & Food products & 1537 & 0.40 & 0.41 & 0.63 & 0.38 \\
\hline & Tobacco & 41 & 0.44 & 0.28 & 0.49 & 0.29 \\
\hline & Textile & 355 & 0.32 & 0.45 & 0.65 & 0.37 \\
\hline & Apparel & 120 & 0.31 & 0.51 & 0.67 & 0.32 \\
\hline & Wood Products & 168 & 0.21 & 0.49 & 0.75 & 0.52 \\
\hline & Furniture & 75 & 0.19 & 0.50 & 0.78 & 0.56 \\
\hline & Paper Products & 402 & 0.41 & 0.40 & 0.63 & 0.37 \\
\hline & Printing and Publishing & 299 & 0.34 & 0.40 & 0.61 & 0.35 \\
\hline & Chemicals & 1804 & 0.41 & 0.40 & 0.65 & 0.42 \\
\hline & Petroleum Refining & 115 & 0.43 & 0.27 & 0.50 & 0.31 \\
\hline & Rubber and Plastics Prod. & 380 & 0.45 & 0.41 & 0.67 & 0.44 \\
\hline & Leather and Leather Prod. & 60 & 0.28 & 0.29 & 0.64 & 0.49 \\
\hline & Stone. Clay. Glass Prod. & 572 & 0.40 & 0.26 & 0.52 & 0.35 \\
\hline & Primary Metal Industries & 708 & 0.34 & 0.26 & 0.53 & 0.37 \\
\hline & Fabricated Metal Prod. & 370 & 0.43 & 0.42 & 0.64 & 0.39 \\
\hline & Machinery and Computer & 754 & 0.45 & 0.45 & 0.67 & 0.41 \\
\hline & Electronic and Electrical & 1164 & 0.40 & 0.42 & 0.63 & 0.37 \\
\hline & Transportation Equip. & 673 & 0.49 & 0.29 & 0.53 & 0.33 \\
\hline & Professional / Scientific & 184 & 0.46 & 0.45 & 0.68 & 0.41 \\
\hline & Miscellaneous Manuf. & 138 & 0.38 & 0.42 & 0.64 & 0.37 \\
\hline
\end{tabular}

Source: Authors' calculations from Thompson's International Mergers and Acquisitions database. \# transactions is the total number of transactions (domestic and foreign). Share foreign is the share of transactions with a foreign acquirer. Share full is the share of full acquisitions ( $100 \%$ stake) in total number of foreign acquisitions. Share acquired is the average share acquired among foreign acquisitions or foreign partial acquisitions (last column).

sectors.

There is also substantial variation in the size of the stake acquired by foreign acquirers. 
On average across target countries and sectors, 39\% of transactions are full acquisitions (i.e., transactions in which the acquirer purchases $100 \%$ of the target), and this share is similar for both foreign and domestic acquisitions (Table A.4 in the online appendix). Partial acquisitions are therefore an important characteristic of the data, a point also documented in Alquist et al. (2016). Within the subset of foreign partial acquisitions, the average share acquired is relatively low $(38 \%)$. As can be seen from Figure 1, which plots the density of the distribution of shares acquired in foreign acquisitions between 0 and 1 inclusive, the distribution for partial acquisitions is bimodal, with many transactions involving a small share acquired and a second peak right above the $50 \%$ cutoff.

The size of the stakes acquired in foreign acquisitions varies widely across target countries. In Mexico and South Africa, about $60 \%$ of foreign transactions are full acquisitions. By contrast, in Thailand and Indonesia, more than $80 \%$ of acquisitions are partial. Likewise, there is heterogeneity across target sectors, with some industries experiencing a larger share of partial acquisitions (e.g., $74 \%$ for primary metals) and others more full acquisitions (e.g. 49\% in wood products). These differences suggest that the incentives affecting an acquirer's decision to purchase part of a firm in a foreign country and those determining the size of the stake are to some extent distinct. Interestingly, countries and sectors in which full acquisitions are more common are not necessarily those in which the stake acquired is large when the acquisition is partial. Full acquisitions in Vietnam and Indonesia, for example, make up a small share of total acquisitions, but within the subset of partial acquisitions in those two countries, the size of the stake acquired tends to be relatively large. The determinants of the decision to purchase a target firm fully and the ones governing the size of the stake acquired in partial acquisitions thus appear distinct. Our model clarifies the role of different factors in determining whether a foreign acquisition occurs and whether it is full or partial.

\subsection{A first look at the role of financial constraints}

These patterns suggest that the likelihood of foreign acquisitions and their average size may be driven by both industry- and country-level factors for the target, a view consistent with the results of Moeller et al. (2005) and Erel et al. (2012). Figures 2.a to 2.d show that an industry's level of external finance dependence and the target country's level of financial of development are plausible candidates for these common driving forces. We use Rajan and Zingales's measure of external finance dependence at the SIC 2-digit level Rajan and Zingales (1998) and the average ratio of private credit to GDP over the period from the World Bank Development Indicators as a measure of financial development to make these figures.

Both the probability of foreign acquisition and the size acquired are positively correlated with the Rajan-Zingales measure of external finance dependence. That is, credit constraints seem to be an important friction that affects the pattern of foreign acquisitions. On the other hand, target countries with a lower level of financial development tend to experience more foreign acquisitions. The correlation between the share acquired by foreign firms and financial development is less clear.

The model in the next section provides a framework that directly relates the size of a foreign acquisition to the credit constraints facing the target as well as to country-level financial fric- 
Figure 2: Liquidity and foreign acquisitions: correlations

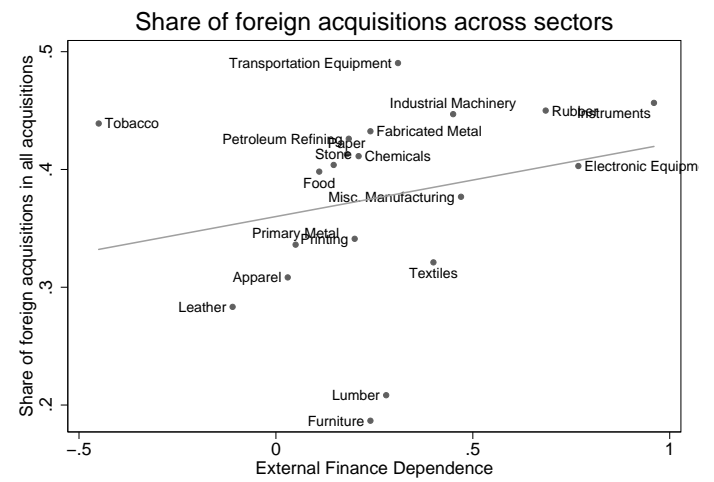

(a) Foreign acquisitions and external dependence

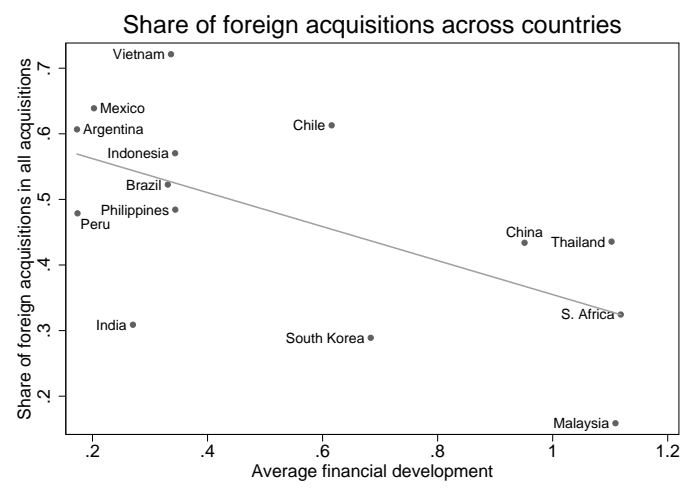

(c) Foreign acquisitions and financial development

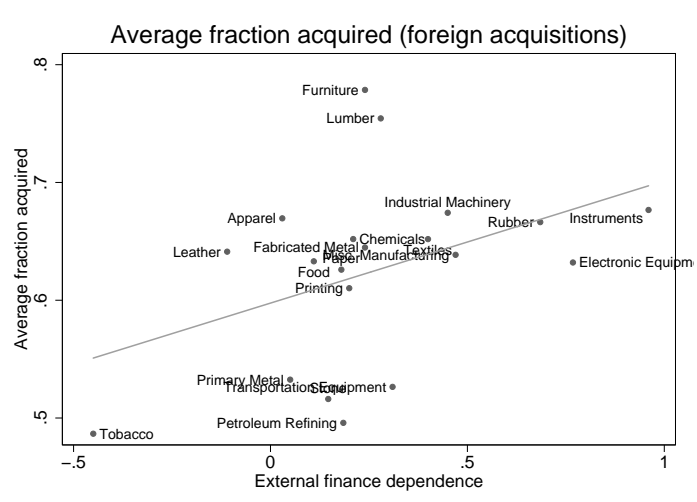

(b) Share acquired and external dependence

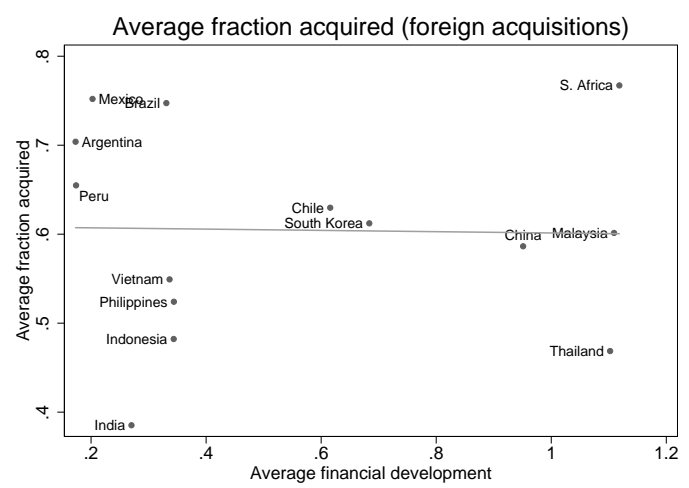

(d) Share acquired and financial development

Note: These figures plot the ratio of foreign acquisitions over all acquisitions (Figures (a) and (c)) and average share acquired conditional on a foreign acquisition being observed (Figures (b) and (d)) against the target industry's external finance dependence (Figures (a) and (b)) or the target country's average ratio of private credit over GDP over the period (Figures (c) and (d)).

tions. It shows that institutional quality matters for the share acquired beyond the effect of the level of financial development. In countries with better institutions, foreign acquirers are more likely to purchase all of the target firm. It also shows that the determinants of the decision to undertake a full acquisition are not the same as those that influence the size of acquisitions in partial acquisitions. This prediction has implications for the interpretation of the raw correlations of Figure 2. It implies that (i) they omit an important factor, institutional quality; and (ii) they should consider separately full and partial acquisitions. The empirical analysis shall support these statements. In particular, we will find that, controlling for institutional quality, the correlation between the share acquired by foreign firms and financial development becomes much clearer in the case of full acquisitions.

\section{A model of cross-border acquisitions}

We next develop a simple two-period model of cross-border acquisition that provides a number of testable implications. The model highlights the interaction between two main sets of factors 
as determinant of ownership structure in cross-border acquisitions. The first, consists of two financial factors: the extent of the target firm's sectoral dependence on external finance and the financial development of the country in which it is located. The second, is a set of institutional barriers that foreign owners face when operating a firm in an emerging market, specifically, those barriers that can be mitigated by having partial domestic ownership in the firm. Because the purpose of the model is to provide a framework for the empirical analysis, we provide a brief description of the key mechanisms of the model, while the statements and the proofs of the propositions are provided in the online appendix (section A.1, pages ii-xiii). In this section, references to page numbers in the online theory appendix use Roman numerals.

\subsection{Model description}

The model consists of a domestic firm operating in an emerging market (the target) and a foreign firm (the acquirer) that has the choice of obtaining full ownership of the target, a partial stake in the target or no stake in the target. While the model has some auxiliary predictions for the "no acquisition" decision (i.e., the probability of a foreign acquisition), we focus on the trade-offs involved in choosing between full or a partial stake in the target. ${ }^{12}$

\subsubsection{Domestic firm's problem}

To start the analysis, consider the production decision facing the target firm in country $c$ in industry $i$ that is fully owned by domestic residents. ${ }^{13}$ The firm operates for two periods. Production requires capital, $I_{i c}$, and an input $L_{i c}$, which we call a "local" input for reasons clarified below. We assume the production function is Cobb Douglas, $F\left(I_{i c}, L_{i c}\right)=A_{i c, 2} I_{i c}^{\beta_{I}} L_{i c}^{\beta_{L}}$ where $A_{i c, 2}$ denotes the productivity of the firm in period 2. There are decreasing returns to scale $\left(\beta_{I}+\beta_{L}<1\right)$, which could be due to the presence other inputs such as local infrastructure provided by the government which we do not model explicitly (see Asiedu and Esfahani, 2001, for a treatment of this problem).

The average firm in sector-country unit $i c$ may be heterogenous along many dimensions. This is captured in our model by $A_{i c, 2}$, which we call "productivity". Heterogeneity in $A_{i c, 2}$ plays a key role in our model: it forms the link between the target firm's financial constraints and institutional constraints faced by the foreign acquirer for reasons that will be explained later.

Capital fully depreciates within a period so all capital needed for production must be obtained before period 2 . The analysis starts at the end of period 1 when the firm has profits $\pi_{i, 1}$ from operating the firm in period 1 and must choose $I_{i c}$ to be able produce in period 2. $I_{i c}$ must therefore be financed from available internal funds, $\pi_{i, 1}$, and if those are insufficient, by external borrowing up to $\bar{D}_{i c}$. We assume that a firm in country $c$ can only borrow up to a fraction $\tau_{c}$

\footnotetext{
${ }^{12}$ Empirically, studying the binary decision of the foreign firm to acquire a domestic one would require observing the full set of potential targets. We do not observe this set in our data and therefore concentrate on the share of foreign acquisitions in all acquisitions. On the other hand, our data permit us to identify the stake acquired by foreign firms within the set of realized cross-border transactions, which is why the model concentrates on these predictions. In addition, while most prior research has focussed on the probability of foreign acquisitions, the determination of foreign ownership structures in M\&A has received less attention.

${ }^{13}$ Variables are subscripted by $i$ denoting industry and $c$ denoting country to conform to our later empirical implementation, where the data varies along the industry, country $\times$ time, and industry $\times$ country $\times$ time dimensions.
} 
of its capital $I_{i c}$, i.e., $\bar{D}_{i c}=\tau_{c} I_{i c}$. The transaction cost $\tau_{c}$ is specific to country $c$ and captures differences in financial development across countries. We interpret high values of $\tau_{c}$ as higher financial development in $c$, in the sense that its financial system is more efficient in creating loans from the available collateral $I_{i c}$. We then have $I_{i c} \leq \bar{D}_{i c}+\pi_{i, 1} \equiv l_{i c}$ which by substitution yields the investment constraint

$$
I_{i c} \leq \frac{\pi_{i, 1}}{\left(1-\tau_{c}\right)} \equiv l_{i c}
$$

Firm liquidity in period 1 is defined as $l_{i c} \equiv \bar{D}_{i c}+\pi_{i, 1} \in[\underline{l}, \bar{l}]$.

The amount of liquidity available to the firm thus depends on $\pi_{i, 1}$ and $\tau_{c}$. An industry that is dependent on external finance has a ratio of profits to the firm's need for capital that is low; i.e., firms in that industry rely more heavily on other sources of finance. Following Rajan and Zingales (1998), we assume that external finance dependence is the same across countries for a particular sector $i$. Equation 3.1 also shows that the firm's liquidity is increasing in $\tau_{c}$; the higher is financial development, the more the firm will be able to borrow to finance investment. We consider the problem of a constrained firm that invests up to its liquidity constraint, where $l_{i c}=\frac{\pi_{i, 1}}{\left(1-\tau_{c}\right)}$. Taking that level of investment as given by its financial constraint, the firm then chooses the local input to maximize its value $V_{i c}^{D, 0}$,

$$
V_{i c}^{D, 0} \equiv \max _{L_{i c}}\left\{\pi_{i, 1}+A_{i c, 2} l_{i c}^{\beta_{I}} L_{i c}^{\beta_{L}}-l_{i c}-p L_{i c}\right\}
$$

where the " 0 " superscript denotes the amount of foreign ownership in the firm and $p \neq 1$ is the relative price paid by the domestic agent for the local input. ${ }^{14}$ The stand-alone value of the domestic firm is $V_{i c}^{D, 0}$, which is increasing in liquidity (and therefore first-period profits and the level of financial development since $l_{i c} \equiv \frac{\pi_{i, 1}}{\left(1-\tau_{c}\right)}$ ) when the financial constraint binds. The direction of these effects is intuitive and so to conserve space, the proof of these results are shown in the online appendix (section A.1, pages ii-iii). $V_{i c}^{D, 0}$ represents the outside option for the domestic owners of the firm when faced with an acquisition offer, which is analyzed below.

\subsubsection{Foreign acquisitions}

The domestic firm may be the target of a foreign acquisition at the end of period 1 in which a fraction $\alpha_{i c} \in[0,1]$ of the firm is acquired. We assume for simplicity that first-period profits of the domestic firm, $\pi_{i, 1}$, do not change hands. We also assume that foreign acquirers have greater access to funds and therefore do not face the financing constraints that confront the emerging market target.

The acquisition requires a fixed cost $\Gamma$ for the acquirer for any level of ownership, $\alpha_{i c}>0$, which represents costs that influence the overall profitability of entering the international market for corporate control, such as search and due diligence costs, but do not affect decisions at the margin. We assume that acquisition by a foreign firm brings with it productivity gains for the target, so that post-acquisition productivity is $\phi A_{i c, 2}$ with $\phi>1$.

These two elements of the model, $\Gamma$ and $\phi$, are not necessary for our main results but are

\footnotetext{
${ }^{14}$ The price of capital and output are implicity set at 1 . While setting $p=1$ would simplify the algebra and not change any of our results (as shown in the online appendix, section A.2, pages xiii-xix), we let the price of capital (which is a scarce input in the setting we consider) differ from that of the local input to be more general.
} 
included for the sake of realism. When $\Gamma=0$, it is feasible for the foreign firm, even if it has no productivity advantage, to buy any domestic firm, as long as the latter is financially constrained. When $\phi=1$ the only gains from foreign acquisitions come from relieving financial constraints. $\Gamma>0$ and $\phi>1$ are thus meant to capture that: (a) not all firms in emerging markets come to be owned by foreigners; and (b) not all gains from foreign ownership originate from the provision of financing. While (a) is uncontroversial, (b) is consistent with a large body of empirical evidence about the productivity or value gains from FDI in general (see Yasar and Morrison Paul, 2007; Blalock and Gertler, 2008; Arnold and Javorcik, 2009), and emerging market acquisitions in particular (see Chari et al., 2010; Bris and Cabolis, 2008). That $\Gamma$ does not affect any of our comparative static results can be easily seen, since it enters as a fixed cost and thus does not affect any decisions at the margin. The parameter $\phi$ is not necessary for our qualitative results but affects their magnitude, as shown in the online appendix (see, underlined text in section A.1, pages iii-x). We briefly describe the intuition behind these effects when we describe our hypotheses in a later section. The online appendix (section A.2, pages xiii-xix) also solves a simplified version of the model without fixed costs of acquisitions $(\Gamma=0)$ and productivity spillovers $(\phi=1)$ to show that all our results are insensitive to these two assumptions.

While the elements described above are common to full and partial foreign acquisitions key difference between full and partial acquisitions is the assumption that when the target is acquired in its entirety $\left(\alpha_{i c}=1\right)$, the foreign owner is at a comparative disadvantage in procuring the local input. This could be due to a lack of knowledge about local labor and product markets, weaker political connections, or a domestic bias in the preferences of bureaucrats or regulators. We model this by assuming that the foreign firm pays a county-specific markup for the local input, $\omega_{c}>1$, where the magnitude of $\omega_{c}$ captures the extent to which the foreign firm's marginal cost for the input is higher than that of a local firm.

\subsubsection{Foreign acquirer's problem (full acquisition)}

Given these assumptions, a full acquisition is basically the purchase of rights to produce using the technology of the domestic firm. The value of the domestic firm to a foreign owner who undertakes a full acquisition $\left(\alpha_{i c}=1\right)$ is given by

$$
V_{i c}^{F, 1} \equiv \max _{I_{i c}, L_{i c}}\left\{\phi A_{i c, 2} I_{i c}^{\beta_{I}} L_{i c}^{\beta_{L}}-I_{i c}-\omega_{c} p L_{i c}-\Gamma\right\}
$$

Denote by $S_{i c}^{F, 1}$ the profit accruing to the foreign acquirer from the acquisition when it acquires full ownership $\left(\alpha_{i c}=1\right)$. We assume that the price paid in the acquisition, $P_{(1)}$, is such that the domestic firm's payoff is its reservation value $V_{i c}^{D, 0}$. Thus $P_{(1)}=V_{i c}^{D, 0}-\pi_{i, 1}$. For the foreign firm, then, $S_{i c}^{F, 1}=V_{i c}^{F, 1}-P_{(1)}=V_{i c}^{F, 1}+\pi_{i, 1}-V_{i c}^{D, 0} \cdot{ }^{15}$ A necessary (but not sufficient) condition for a full acquisition to be optimal for the foreign acquirer is thus:

$$
S_{i c}^{F, 1} \geq 0
$$

\footnotetext{
${ }^{15}$ We show in the online appendix (section A.3, page $\mathrm{xx}$ ) that this is equivalent to assuming that the acquirer and target are involved in Nash bargaining over the acquisition price but the target has no bargaining power. Hence the acquirer retains all the surplus.
} 


\subsubsection{Foreign acquirer's problem (partial acquisition)}

The foreign firm might instead choose to acquire partial ownership if it finds direct procurement of the local input too costly. In this case, it buys an equity claim on a share $\alpha_{i c}<1$ of second period profits and provides all of the capital, $I_{i c}$. A share $\left(1-\alpha_{i c}\right)$ of second period profits, as well as any liquid assets from period 1 , are retained by the domestic owner, who also provides the local input at the price $p \leq \omega_{c} p$.

Under partial foreign ownership, the second period payoffs for the foreign acquirer and the domestic owner are given by $V_{i c}^{F, \alpha_{i c}} \equiv \alpha_{i c}\left(\phi A_{i c, 2} I_{i c}^{\beta_{I}} L_{i c}^{\beta_{L}}\right)-I_{i c}-\Gamma-P_{\left(\alpha_{i c}\right)}$ and $V_{i c}^{D, \alpha_{i c}} \equiv$ $\left(1-\alpha_{i c}\right)\left(\phi A_{i c, 2} I_{i c}^{\beta_{I}} L_{i c}^{\beta_{L}}\right)-p L_{i c}+P_{\left(\alpha_{i c}\right)}$, respectively. $P_{\left(\alpha_{i c}\right)}$ is the price paid by the foreign acquirer to the domestic owner for $\alpha_{i c}$ of the equity of the firm. We follow Asiedu and Esfahani (2001) in assuming that $P_{\left(\alpha_{i c}\right)}$ is a fixed proportion $\kappa$ of the foreign acquirer's share in the period 2 revenues of the acquired firm, so that $P_{\left(\alpha_{i c}\right)}=\kappa \alpha_{i c}\left(\phi A_{i c, 2} I_{i c}^{\beta_{I}} L_{i c}^{\beta_{L}}\right)$. This assumption simplifies the algebra considerably, but influences a subset of our results. Hence we discuss it in more detail at the end of section 3.2 where we also provide an interpretation for the parameter $\kappa$.

The game between the acquiring and target firm is solved by backward induction starting from the second (production) stage to the first (acquisition) stage

Second Stage: The foreign acquirer maximizes $V_{i c}^{F, \alpha_{i c}}$ with respect to $I_{i c}$ taking $L_{i c}$ and $\alpha_{i c}$ as given, while the domestic co-owner maximizes $V_{i c}^{D, \alpha_{i c}}$ with respect to $L_{i c}$ taking $I_{i c}$ and $\alpha_{i c}$ as given. The first order conditions to this pair of input choice problems gives reactions functions $I_{i c}=I_{i c}\left(L_{i c}, \alpha_{i c}\right)$ and $L_{i c}=L_{i c}\left(I_{i c}, \alpha_{i c}\right)$. From these we can solve for the Nash-equilibrium levels of inputs supplied as functions $I_{i c}\left(\alpha_{i c}\right)$ and $L_{i c}\left(\alpha_{i c}\right)$ of the equity stake $\alpha_{i c}$. Intuitively, varying ownership of the revenue stream changes the incentives to provide the input.

First Stage: The acquirer takes these incentive compatible input decisions in the second stage as given when choosing the optimal ownership share, $\alpha_{i c}$, in the first stage of the game, while satisfying the participation constraint of the domestic owner. ${ }^{16}$ Formally, the foreign firm maximizes its own profits from the acquisition in the first stage:

$$
S_{i c}^{F, \alpha_{i c}} \equiv \max _{\alpha_{i c}}\left\{\alpha_{i c}(1-\kappa)\left(\phi A_{i c, 2} I_{i c}\left(\alpha_{i c}\right)^{\beta_{I}} L_{i c}\left(\alpha_{i c}\right)^{\beta_{L}}\right)-I_{i c}\left(\alpha_{i c}\right)-\Gamma\right\},
$$

subject to the domestic agent's participation constraint,

$$
\begin{aligned}
V_{i c}^{D, \alpha_{i c}} & \equiv\left(1-\alpha_{i c}(1-\kappa)\right)\left(\phi A_{i c, 2} I_{i c}\left(\alpha_{i c}\right)^{\beta_{I}} L_{i c}\left(\alpha_{i c}\right)^{\beta_{L}}\right)-p L_{i c}\left(\alpha_{i c}\right) \geq V_{i c}^{D, 0}-\pi_{i, 1},(3 . \\
\text { or, } S_{i c}^{D, \alpha_{i c}} & \equiv V_{i c}^{D, \alpha_{i c}}+\pi_{i, 1}-V_{i c}^{D, 0} \geq 0
\end{aligned}
$$

A necessary condition for full ownership to be chosen by the foreign acquirer is that

$$
S_{i c}^{F, 1} \geq S_{i c}^{F, \alpha_{i c}}
$$

If $S_{i c}^{F, 1}<S_{i c}^{F, \alpha_{i c}}$, the foreign acquirer prefers partial ownership as long as $S_{i c}^{F, \alpha_{i c}} \geq 0$.

\footnotetext{
${ }^{16}$ This constraint is one of the key differences between our paper and Asiedu and Esfahani (2001). The outside option of the domestic firm in Asiedu and Esfahani (2001) is normalized to zero and does not play any role in their results. By contrast, the liquidity-dependent outside option of the domestic owner is central to our analysis.
} 
This concludes the description of the model. In an accompanying online appendix (section A.1, pages ii-xiii) we provide a detailed analysis of foreign acquisitions across different countries and industries using the model sketched above. The main comparative statics we perform relate to changes in: (i) the degree of external finance dependence of an industry (the first period profit of the representative firm in industry $i, \pi_{i, 1}$ ); (ii) the financial development of country $c$ (the pledgability parameter $\tau_{c}$ ); and (iii) the relative disadvantage the foreign firm faces in operating a fully owned firm as opposed to owning it partially in country $c$ (the markup $\omega_{c}$ ). The complete statement of these results, and their proofs, are provided in the online appendix (specifically, section A.1, pages xi-xiii). In the next section, we state a few empirical hypotheses originating in these results and clarify the intuition behind them using Figure 3 below.

\subsection{Economic intuition and empirical hypotheses}

The main choices facing the foreign firm are: (a) whether to buy a domestic target at all; if yes, (b) whether to take full or partial ownership; if the latter, (c) how much partial ownership to acquire. When making these decisions, it is useful from the point of view of the foreign firm to evaluate the profitability of acquiring targets according to their liquidity and any other relevant dimensions of heterogeneity (for example, how productive they are). Accordingly, Figure 3 plots the foreign acquirer's iso-profit curves on the plane of target industry liquidity $l_{i c}$ (on the horizontal axis) and a variable $A_{i c, 2}$ (on the vertical axis) that we label as "productivity" for concreteness. Before describing the iso-profit curves, we note that any point on the plane should be thought of as a representative firm in a sector of the economy that has a particular combination of average productivity and external finance dependence. ${ }^{17}$ In our regression analysis we will use empirical proxies for all the key elements included in Figure 3, such as sectoral external finance dependence and productivity. Because the purpose of Figure 3 is to provide intuition, it is generated by simulating the model for parameter values that ease exposition. Thus the reader should not attach particular significance to the cardinal aspects of Figure 3 such as the origin and scale of the axes.

We now discuss two key iso-profit curves for the foreign acquirer in turn.

The curve $A A^{\prime}$ : This depicts combinations of $l_{i c}$ and $A_{i c, 2}$ that result in zero profits from a full acquisition, i.e., $S_{i c}^{F, 1}=0$. Because higher productivity of the target industry is associated with higher profits on average, $S_{i c}^{F, 1}>0$ for all combinations of $l_{i c}$ and $A_{i c, 2}$ to the north of the curve $A A^{\prime}$.

The straight line $C C^{\prime}$ : This depicts combinations of $l_{i c}$ and $A_{i c, 2}$ that result in zero profits from a partial acquisition, i.e., $S_{i c}^{F, \alpha_{i c}}=0$. Following the same logic as for $A A^{\prime}, S_{i c}^{F, \alpha_{i c}}>0$ for all combinations of $l_{i c}$ and $A_{i c, 2}$ north of $C C^{\prime}{ }^{18}$

\footnotetext{
${ }^{17}$ For example, points in the southwest corner of Figure 3 represent sectors that, in our sample of emerging markets, are external finance dependent and whose firms have low productivity on average (e.g. "professional and scientific equipment"), while those to the northeast denote productive sectors whose firms are relatively less external finance dependent (e.g. "apparel").

${ }^{18}$ The $C C^{\prime}$ line is drawn for the case in which the participation constraint for the domestic firm does not bind, so that the optimal share is not influenced by $l_{i c}$ and instead determined by technological factors. Hence $C C^{\prime}$ is flat. This point is discussed further shortly.
} 


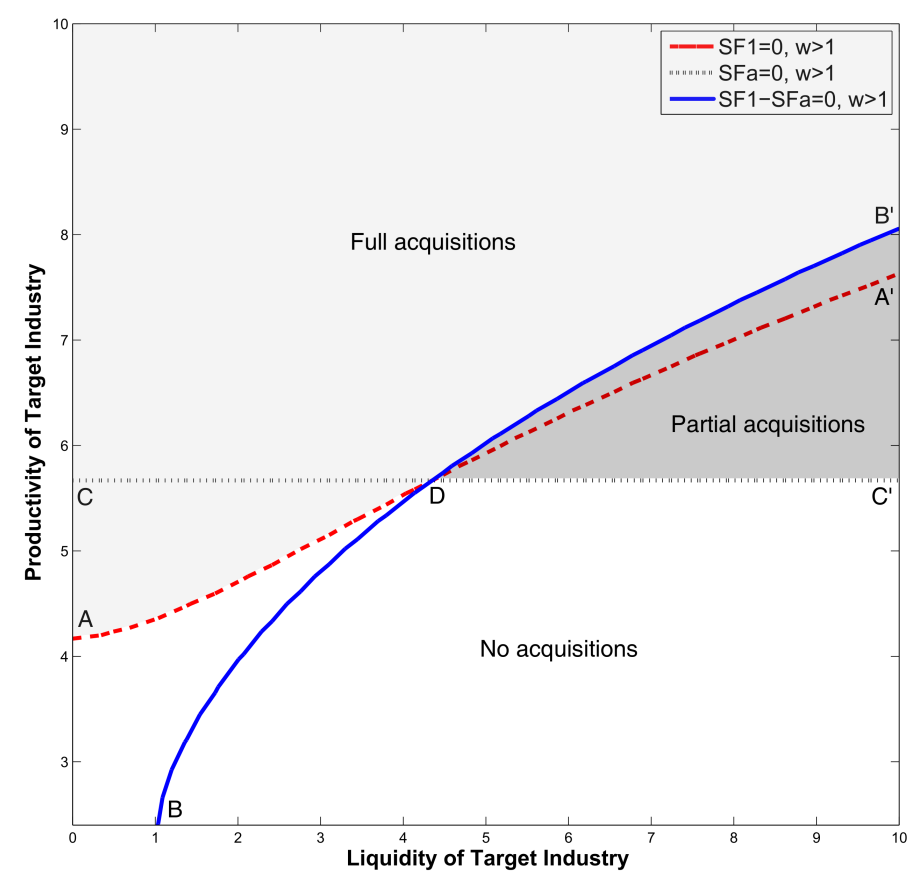

(a) $S_{i c}^{F, 1}=0, S_{i c}^{F, \alpha_{i c}}=0$ and $S_{i c}^{F, 1}-S_{i c}^{F, \alpha_{i c}}=0$ for $\omega_{c}>1$

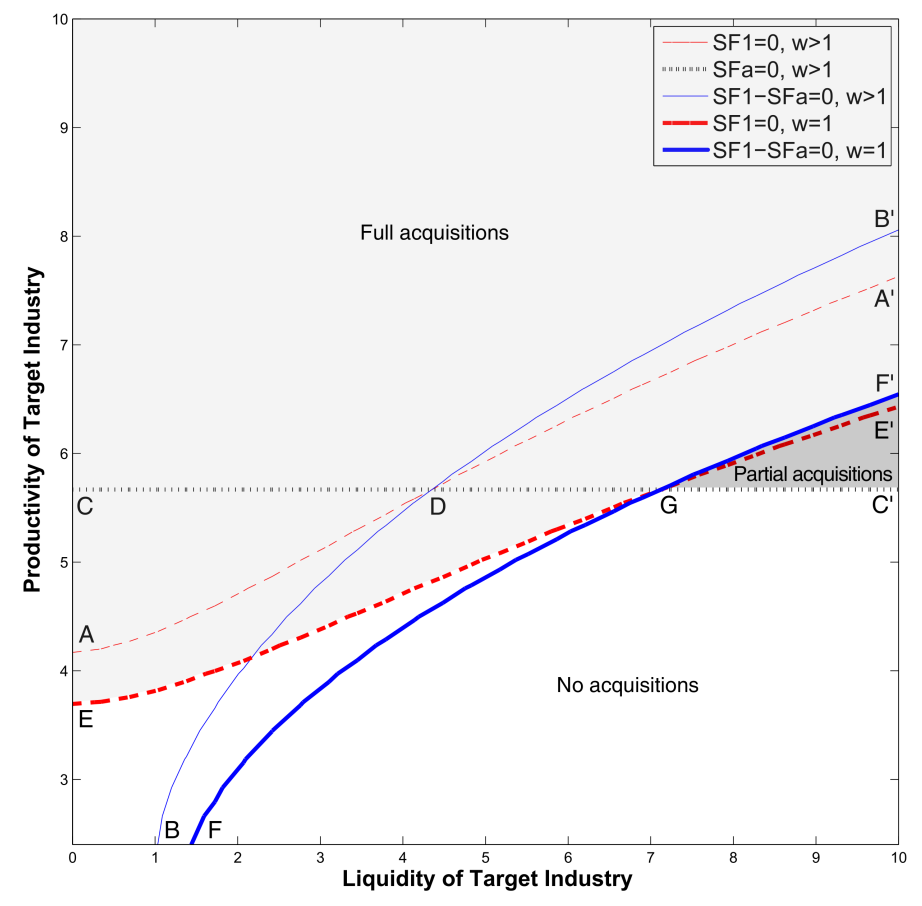

(b) Shifts in $S_{i c}^{F, 1}=0$ and $S_{i c}^{F, 1}-S_{i c}^{F, \alpha_{i c}}=0$ for $\omega_{c}=1$

Figure 3: Liquidity, Productivity and Ownership Structure

Notes: Panel (a) shows combinations of target industry liquidity $l_{i c}$ (plotted on the horizontal axis) and productivity $A_{i c, 2}$ (on the vertical axis) that result in $S_{i c}^{F, 1}=0, S_{i c}^{F, \alpha_{i c}}=0$ and $S_{i c}^{F, 1}-S_{i c}^{F, \alpha_{i c}}=0$ when $\omega_{c}>1$, i.e., foreign firms pay a markup for the local input above the price paid by domestic firms. Panel (b) shows the shifts in $S_{i c}^{F, 1}=0$ and $S_{i c}^{F, 1}-S_{i c}^{F, \alpha_{i c}}=0$ when there is no markup $\left(\omega_{c}=1\right)$. 
The combinations of $l_{i c}$ and $A_{i c, 2}$ for which either $S_{i c}^{F, 1}>0$ or $S_{i c}^{F, \alpha_{i c}}>0$ defines the region in which the foreign acquirer finds it profitable to acquire a domestic firm, either fully or partially. In panel (a) of Figure 3, this set is represented by the shaded regions above $A D C^{\prime}$. The unshaded area of Figure 3(a) depicts those combinations of $l_{i c}$ and $A_{i c, 2}$ where no foreign acquisitions take place: Domestic firms in that region are either too liquid or too unproductive to make them worthwhile targets.

Now, conditional on an acquisition being profitable (i.e., within the shaded areas above $A D C^{\prime}$ ), the foreign acquirer decides to acquire the firm fully if $S_{i c}^{F, 1} \geq S_{i c}^{F, \alpha_{i c}}$, and partially otherwise. This choice is depicted using the curve $B B^{\prime}$.

The curve $B B^{\prime}$ : This depicts combinations of $l_{i c}$ and $A_{i c, 2}$ that result in the same level of profit from a full or partial acquisition, i.e., $S_{i c}^{F, 1}-S_{i c}^{F, \alpha_{i c}}=0$. On this curve the foreign acquirer is indifferent between these two options. It is shown in the online appendix that a full acquisition dominates partial acquisitions north of $B B^{\prime}$ (section A.1, pages viii-x). Thus, full acquisitions are optimal for combinations of $l_{i c}$ and $A_{i c, 2}$ on or above the curve $A D B^{\prime}$, shown in Figure 3 as the light-shaded area. Alternately, partial acquisitions are preferred to full acquisitions in the dark-shaded triangular region $B^{\prime} D C^{\prime}$.

It is instructive to focus on the economic intuition at a few key points in the figure. At points below the line $A D$, targets are in illiquid sectors, yet not productive enough to make it worthwhile for the foreign acquirer to pay the fixed cost of an acquisition. Starting at point $A$ and moving along $A D$, full acquisitions are optimal for any point on or vertically above $A D$ because the targets in those sectors are productive enough on average. The $A D$ line is positively sloped because a more liquid target has to be bought at a higher price and hence needs to be more productive to make the acquisition worthwhile. Points to the right of the line $D B^{\prime}$ represent sectors with relatively low need for external finance, and where existing firms would be more expensive to buy outright. Hence a foreign acquirer prefers a partial acquisition in those sectors when it is able to cover the fixed cost of an acquisition. At points below $D C^{\prime}$, however, sectors are not productive enough even for partial acquisitions to be worthwhile.

We show in the online appendix (section A.1, page iv) that a decline in the local input price markup shifts the $S_{i c}^{F, 1}=0$ curve downwards and towards the right. This shift is shown in panel (b) of Figure 3 as $A A^{\prime}$ moving to $E E^{\prime}$. Intuitively, a decrease in the local input price markup increases the profit from a full acquisition for each level of liquidity of the target, thereby lowering the productivity threshold of the target sector for which an acquisition is profitable to the foreign acquirer. Of note, since the domestic owner provides the local input at the lower price when an acquisition is partial, a change in the markup does not affect the payoffs from a partial acquisition, leaving the $S_{i c}^{F, \alpha_{i c}}=0$ line unchanged. The downward shift of the $S_{i c}^{F, 1}=0$ line and the unchanged $S_{i c}^{F, \alpha_{i c}}=0$ line in turn imply that the $S_{i c}^{F, 1}-S_{i c}^{F, \alpha_{i c}}=0$ curve also shifts downward (see section A.1 of the online appendix, page $\mathrm{x}$ ). This is depicted in panel (b) of Figure 3 as $B B^{\prime}$ moving to $F F^{\prime}$. As a consequence, a lower $\omega_{c}$ is associated with a larger full foreign acquisition set, the light shaded area above $E G F^{\prime}$, and a smaller partial acquisition set $F^{\prime} G C$ (dark shaded).

Based on these insights, we use Figure 3 to explain our first set of empirical hypotheses concerning the effects of external finance dependence, financial development, and the local input 
price markup on the likelihood of full versus partial foreign acquisitions. The proofs of the propositions underlying these hypotheses can be found in the online appendix (section A.1, pages xi-xiii).

\section{Hypothesis 1 Likelihood of Acquiring Full Ownership}

(a) Direct effects: The probability of a full acquisition, conditional on a foreign acquisition taking place, is higher in: (i) external finance dependent target sectors, (ii) in countries with lower levels of financial development, and (iii) in countries that have a lower local input price markup.

(b) Interaction effects: Domestic financial development lowers the likelihood of a full foreign acquisition by more in external finance dependent sectors. A lower local input price markup increases the likelihood of a full foreign acquisition by more in external finance dependent sectors.

The intuition for these hypotheses can be most easily grasped from Figure 3 by examining the area above $D C^{\prime}$ where either full or partial foreign acquisitions can take place depending on the values of $l_{i c}$ and $A_{i c, 2}$. First, starting on any point above $C^{\prime}$ on the boundary of the figure, moving horizontally (i.e., for a given level of average productivity) from right to left towards more external finance dependent sectors moves us into the zone of full foreign acquisitions. In other words, conditional on a foreign acquisition, full or partial, taking place, the representative firm in a more external finance dependent sector is more likely to be acquired fully, ceteris paribus. Second, holding both external finance dependence and productivity fixed, higher financial development leads to the representative firm in all sectors to move towards higher values of liquidity since $l_{i c}=\frac{\pi_{i, 1}}{\left(1-\tau_{c}\right)}$, i.e., more developed financial systems can transform the same amount of pledgable internal funds into a higher quantity of available liquidity. This moves the representative firm into the zone of partial acquisitions to the right. Thus full foreign acquisitions are less likely in countries that are more financially developed. Third, it is also clear from inspection of panel (b) of Figure 3 that a lower local input price markup increases the region in which full foreign acquisitions are chosen over partial acquisitions from the area above $A D B^{\prime}$ to the area above $E G F^{\prime}$, thereby increasing the proportion of full acquisitions within the pool of foreign acquisitions. Intuitively, a lower local input price increases the relative surplus from a full acquisition and makes it more likely for the foreign acquirer to dispense with a local owner. $^{19}$

The interaction effect of external finance dependence with financial development can be understood as follows. Recall that $l_{i c}=\frac{\pi_{i, 1}}{\left(1-\tau_{c}\right)}$, where higher $\tau_{c}$ implies higher financial development. Higher $\tau_{c}$ relieves the credit constraints of domestic firms (increases $l_{i c}$ ), thereby increasing the level of investment, since constrained firms invest $l_{i c}$. However the biggest marginal effects of the increase in investment on the value of the domestic firm are seen when investment is at a low level, i.e., in external finance dependent sectors. Intuitively, small improvements in financial development have large positive effects on the stand-alone value of the domestic firm (its outside option) in financially constrained sectors, lowering the likelihood of full foreign acquisitions by

\footnotetext{
${ }^{19}$ The effect of higher productivity can be seen as follows. starting on any point on the segment $D C^{\prime}$, moving up vertically (for a given level of external finance dependence of a sector) from less to more productive sectors moves us into the zone of full foreign acquisitions. In other words, conditional on a foreign acquisition taking place, the representative firm in a more productive sector is more likely to be acquired fully, ceteris paribus.
} 
relatively more in those sectors. In turn, the interaction effects of external finance dependence with the local input price markup can be understood as follows. Panel (b) of Figure 3 shows that, since a greater proportion of partial acquisitions take place at higher levels of $l_{i c}$, the effects of changes in $\omega_{c}$ are focussed on the lower ranges of $l_{i c}$ values, i.e., in more external finance dependent sectors. ${ }^{20}$

Next, we outline the hypotheses regarding the determinants of the size of the stake acquired within the subset of partial foreign acquisitions.

\section{Hypothesis 2 Size of Stakes in Partial Foreign Acquisitions}

The size of stakes in partial foreign acquisitions is weakly higher in (i) external finance dependent target sectors, and in (ii) countries with lower financial development; (iii) it is not sensitive to the local input price markup.

In the online appendix (section A.1, Lemma 1, pages viii-ix) we show that the unconstrained problem (i.e., ignoring the domestic firm's participation constraint equation 3.6) of the determination of an optimal partial foreign ownership share has an analytical solution, which is $\alpha_{i c}=\frac{1-\beta_{L}}{1-\kappa}$. In words, foreign ownership is negatively related to the factor elasticity (or share) of the local input in the production process as in Asiedu and Esfahani (2001). Intuitively, the foreign acquirer takes a lower equity stake the more important the local input is in production, leaving a higher stake for the domestic owner. However, there arise two cases, one in which financial factors are important and one in which they are not, depending on whether or not the participation constraint binds. The first case occurs when the local input is of sufficient importance in the production process so that the equity share in profits that motivates the domestic firm to provide it optimally is also sufficient to satisfy her participation constraint. The resulting ownership structure in this case is dictated by the technological solution above and not dictated by financial considerations. Figure 3 shows $S_{i c}^{F, \alpha_{i c}}=0$ for this case to simplify the graphical exposition of the model.

The second case occurs when the participation constraint binds. This may happen when the local input is of relatively low importance. In this case, the technological optimum shown above will dictate a low ownership share, and hence a low share of the surplus, for the domestic owner, which however may not be enough to satisfy her participation constraint. If it binds, the equity shares are dictated only by the domestic agent's participation constraint and is simply the solution that guarantees the domestic owner her reservation value (i.e., the solution to $S_{i c}^{D, \alpha_{i c}}=0$, see equation 3.6). It is shown in the online appendix (section A.1, Lemma 2, pages ix-x) that in this case the foreign ownership share depends negatively on liquidity, which in turn implies that higher foreign stakes are more likely in external finance dependent sectors and less financially developed countries.

Since the technological importance of the local input is likely to vary across sectors, the average estimated relationship between liquidity and the size of partial ownership stakes will be

\footnotetext{
${ }^{20}$ The shift displayed in panel (b) of Figure 3 is for a reduction of $\omega_{c}$ to a value of 1, i.e., the foreign firm pays exactly the same price for the local input as the domestic firm. Yet, there remains an area $G F^{\prime} C^{\prime}$ where partial acquisitions are still optimal. These partial acquisitions involve high-liquidity targets that are productive enough to be acquired, but not productive enough to justify buying out the domestic owner completely. This extreme case shows that a partial acquisition may be undertaken to lower the cost of local inputs as well as when a full acquisition of a liquid but unproductive target is too expensive.
} 
an average over sectors in which target liquidity is immaterial and for which it is not. Empirically, we therefore expect a weak positive relationship between the size of foreign stakes acquired in partial acquisitions, and the degree of external finance dependence of a sector (or a weak negative one with the financial development of a country).

Regarding the relationship between the local input price markup and the size of stakes, recall from the discussion of panel (b) of Figure 3 that a change in $\omega_{c}$ is not reflected in the $S_{i c}^{F, \alpha_{i c}}=0$ curve. Intuitively, within the subset of foreign acquisitions where having partial domestic ownership is optimal and the price paid for the local input is always $\omega_{c}$, the size of the stake given to the domestic owner will not depend on the local input price at the margin. ${ }^{21}$

In the discussions of all the hypotheses above, we conditioned the outcome variables on a foreign acquisition - full or partial - taking place. In other words, our model also has implications for the overall likelihood of foreign acquisitions. However, as explained in a later section, we only have an imperfect empirical proxy to pin down this likelihood, and hence consider the following hypotheses as interesting corollaries to our central results on the determinants of foreign ownership structure.

\section{Hypothesis 3 Corollary on the Overall Likelihood of Foreign Acquisitions}

(a) Direct effects: The probability of a foreign acquisition is higher in: (i) external finance dependent target sectors, (ii) in countries with lower levels of financial development, and (iii) in countries that have a lower local input price markup.

(b) Interaction effects: Domestic financial development lowers the likelihood of a foreign acquisition by more in external finance dependent sectors. A lower local input price markup increases the likelihood of a foreign acquisition by more in external finance dependent sectors.

First, recall that the set of $\left(l_{i c}, A_{i, 2}\right)$ values for which foreign acquisitions, either full or partial, are optimal is given in panel (a) of Figure 3 by the region above $A D C^{\prime}$. This is the union of the areas where full and partial acquisitions are individually optimal. This area can be expressed as a proportion of the total area within the entire range of $l_{i c}$ and $A_{i, 2}$ values in Figure 3 . It is easy to see that this proportion is weakly larger, i.e., foreign acquisitions overall are more likely, for external finance dependent sectors since the vertical distance above $A D C^{\prime}$ is weakly higher for lower values of $l_{i c}{ }^{22}$ It can be similarly reasoned that higher financial development leads to a lower likelihood of foreign acquisitions. As discussed earlier, a lower local input price markup increases the surplus from foreign acquisitions in the cases where full acquisitions are optimal, thereby increasing the region where foreign acquisitions are optimal by the area $A D G E$. This leads to a higher likelihood of foreign acquisitions. The reasoning for the sign of the interaction effects for the overall likelihood of foreign acquisitions is analogous to that for the probability of full foreign acquisitions. ${ }^{23}$

\footnotetext{
${ }^{21}$ In addition the model predicts that there is a weak negative relationship between the size of partial stakes and the average productivity of a sector. The intuition is as follows. In the first case above when the ownership shares are dictated by the input shares in the production process, the average productivity plays no role. In the second case, when the participation constraint binds, since more productive representative firms provide a higher outside option to the domestic owner, she requires more equity as compensation. Thus more productive sectors should see smaller partial foreign stakes. This result runs counter to the higher likelihood of full foreign acquisitions in more productive sectors.

${ }^{22}$ The qualifier weakly is due to the flat part $\left(D C^{\prime}\right)$ of this set.

${ }^{23}$ Similarly, note that the horizontal distance to the left of $A D C^{\prime}$ is weakly higher for more productive sectors,
} 


\subsection{Discussion}

We end this section with a discussion regarding which elements and assumptions of the model, beyond those needed to perform the preceding comparative statics (i.e., external financial dependence $\pi_{i, 1}$, financial development $\tau_{c}$, and institutional quality $\omega_{c}$ ), matter for our results. The additional "free parameters" in the model are: (i) the country-industry productivity $\left(A_{i c}\right)$, (ii) the foreign productivity advantage $(\phi)$, (iii) the fixed cost of doing M\&A $(\Gamma)$, and (iv) the price of the local input for the domestic firm (p). As discussed in the model description, these are introduced for realism. We show in the online appendix (see simplified model, section A.2, pages xiii-xix) that assumptions (ii)-(iv) above are not necessary for any of our comparative static results. The parameter $\phi$ is not necessary for our qualitative results but influences their magnitude in intuitive ways that are derived and discussed in detail in the online appendix (see, parts following underlined text in section A.1, pages iii-x). ${ }^{24}$ The assumption of heterogeneity in $A_{i c, 2}$ is necessary for one of our key results, that the effect on full foreign acquisitions of a lower local input price markup is larger in more external finance dependent sectors. When targets are homogeneous in productivity, only differential liquidity across industries and institutions across countries induce variation in the acquirer's payoffs. Liquidity enters the payoffs of a full acquisition indirectly through the outside option of the domestic firm (which determines how much is to be paid for the acquisition) since foreign-owned firms are unconstrained. In contrast, institutions directly affect the foreigner's profits from running the firm on their own (through the higher price of local inputs paid when the acquisition is full). As a result financial factors and institutions enter through different elements of the payoff from a full acquisition. Mathematically, this means the acquirer's payoff is additively separable in liquidity and institutions. Thus liquidity and institutions do not interact unless there is a variable, namely heterogeneous productivity across targets, that influences the choice of acquiring fully and is present in both the aforementioned elements of the foreigner's payoff from a full acquisition. This is formally shown in the online appendix section A.2 on page xviii.

We model a partial acquisition as a contractual arrangement between the acquirer and the target which involve a side payment. We interpret this side payment $P_{\left(\alpha_{i c}\right)}$ as the acquisition price paid for a stake of size $\alpha_{i c}$ and restrict it to take the form $P_{\left(\alpha_{i c}\right)}=\kappa \alpha_{i c}\left(\phi A_{i c, 2} I_{i c}^{\beta_{I}} L_{i c}^{\beta_{L}}\right)$ to simplify the algebra. In our specific context, this is equivalent to the price per share $P_{\left(\alpha_{i c}\right)} / \alpha_{i c}$ being a fraction $\kappa$ of the payoffs from the acquisition. ${ }^{25}$ This is a natural assumption in the context of the model since $P_{\left(\alpha_{i c}\right)} / \alpha_{i c}$ is essentially an asset price - the share price of the target firm - which should be some discounted value of future payoffs. Thus, one interpretation of $\kappa$

\footnotetext{
i.e., foreign acquisitions overall are more likely in more productive sectors.

${ }^{24}$ Briefly, higher spillovers favors full over partial acquisitions. Intuitively, when spillovers are larger, foreigners are more likely to favor a full acquisition at the margin because it lets them keep a higher share of the gains. Similarly, a decline in $\omega_{c}$ makes full acquisitions more favorable, and more so when spillovers are larger. The spillover parameter does not influence the size of partial stakes when they are technologically determined as described earlier. However, in the case when finance plays a role in partial stakes, if the spillovers from foreign ownership are greater, then the incremental equity stake needed to compensate the domestic owner for her outside option declines.

${ }^{25}$ More specifically, we assume that the price per share $P_{\left(\alpha_{i c}\right)} / \alpha_{i c}$ is a fraction of the revenues from the acquisition. This is done because each party is assumed, also to simplify the algebra, to pay the full cost of the inputs and share only in the revenues. If we assumed that cost sharing involves each party paying some part of the cost of both inputs, we could also assume that $P_{\left(\alpha_{i c}\right)} / \alpha_{i c}$ is a fraction of profits. This would however complicate the algebra without adding any extra insight.
} 
is as a discount factor, where the rate of interest used by the acquirer is $r=\frac{1}{\kappa}-1$. Rewritten in these terms, $P_{\left(\alpha_{i c}\right)} / \alpha_{i c}=\kappa\left(\phi A_{i c, 2} I_{i c}^{\beta_{I}} L_{i c}^{\beta_{L}}\right)=[1 /(1+r)]\left(\phi A_{i c, 2} I_{i c}^{\beta_{I}} L_{i c}^{\beta_{L}}\right)$ which would be analogous to a canonical asset pricing formula. The parameter $\kappa$ can also encapsulate other features of the market for corporate control that affect the price paid in acquisitions, such as the thickness of the market and other institutional or regulatory details.

However, in theory, the acquisition price in partial acquisitions may be some more general function of $\alpha_{i c}$, or a lump sum payment. In the first case, as discussed in Asiedu and Esfahani (2001), as long as the marginal payoff from the side payment for each agent depends on equity shares, the qualitative results regarding $\alpha_{i c}$ will continue to hold. In the second case, if the acquisition price is negotiated without any restrictions at all, it can be shown that the acquirer leaves the domestic target with the technologically optimal stake discussed earlier, and compensates her in proportion to her outside option by increasing or lowering the side payment, i.e., the acquisition price, while keeping foreign and domestic equity stakes at the technologically optimal level. Thus the link between the size of stakes in partial acquisitions and financial constraints is broken if the form of the side payment is left completely unrestricted. This result is shown in the online appendix (section A.3, pages xix-xxii) in an extension of the simplified version of the model mentioned earlier, using a Nash bargaining framework as in Svejnar and Smith (1984). Note that these alternative formulations leave our theoretical results on the trade-off between full and partial stakes (Hypothesis 1), and the likelihood of foreign acquisitions (Hypothesis 3) unchanged. They affect parts (i) and (ii) of Hypothesis 2 by further weakening the effect of financial factors on the size of partial acquisitions.

\section{Empirical analysis and main results}

In this section, we present our econometric strategy for testing the hypotheses in section 3.2. We describe the empirical counterparts to the variables used in the model (section 4.1) as well as additional control variables (section 4.2), and present key summary statistics (section 4.3). We then discuss the main empirical specifications and the results (sections 4.4 to 4.6).

\subsection{Main variables}

The empirical analysis requires measures of the three main parameters of the model that affect the likelihood and ownership structure of foreign acquisitions - financial development $\left(\tau_{c}\right.$ in the model) and local input price markup $\left(\omega_{c}\right)$ at the country level and external finance dependence $\left(\pi_{i, 1}\right)$ at the industry level.

Our measures of external finance dependence and financial development are standard. ${ }^{26}$ The external finance dependence variable is from Rajan and Zingales (1998) and is defined as the ratio of capital expenditures minus cash flow from operations to capital expenditures. The ratio is calculated for each industry using U.S. data from the 1980s. Using this measure for a sample of emerging markets, as we do, assumes that it reflects intrinsic technological features of these industries that are pervasive across countries. Because U.S. financial markets are well developed, external finance dependence should reflect the demand for credit rather than its supply. The key

\footnotetext{
${ }^{26}$ Section B.1 of the online appendix contains the sources and descriptions of the variables used in the paper.
} 
premise is that the supply of credit in the United States is flat and that the data for equilibrium levels of capital expenditures are solely related to the demand for credit.

We measure financial development as the private credit-to-GDP ratio from the World Bank's Global Financial Development Database. Larger values of the variable indicate lower levels of credit constraints. As our model relates cross-country differences in financial development to foreign acquisitions, we use the average of the private credit-to-GDP ratio over the period for each country. We show that the results obtained using the time-varying version of this variable and those obtained using a pre-sample period measure are consistent with the baseline regressions. ${ }^{27}$

To capture the effects of weak institutions in emerging markets that make it relatively costly for foreign owners to operate fully owned firms, captured in the theoretical model by a markup paid only by the foreign owner for the local input, we first use several indices that measure corruption. In the baseline, we use the index of control-of-corruption, from the Worldwide Governance Indicators (WGI) dataset (Kaufmann et al., 2013). This variable captures several dimensions of corruption that may affect the overall business environment. We postulate that higher levels of corruption - that is, lower values of the control-of-corruption index - are associated with decreased transparency in the target country and with a comparative disadvantage of the foreign acquirer in procuring the local input. Put differently, higher levels of the anticorruption index represent a lower markup on the local input price and make it cheaper for the foreign acquirer to procure the local input. Again, we use the country average over the period, because this variable exhibits little variation over time and because it contains many missing values. We also show specifications using alternative measures, such as an alternative anti-corruption measure from Transparency International; an indicator of the quality of government from the International Country Risk Guide ; and a rule of law index from the WGI. The results obtained in the baseline specification are insensitive to changing the specific measure of corruption. Finally, in our robustness exercise we also make use of a sector-specific index of input complexity. Computed by Nunn (2007), it represents the share of differentiated goods (as defined by Rauch, 1999) in the total number of inputs. We expect higher markups over input prices in more complex sectors, especially in countries with weak institutions. ${ }^{28}$

\subsection{Additional variables}

We include several controls in the regressions. First, the model explicitly takes into account the level of productivity of the target's industry. ${ }^{29}$ Thus, we also use the measure of industrylevel productivity relative to that of the United States from Levchenko and Zhang (2016) for each of the countries in the sample. ${ }^{30}$ Second, in some specifications we include a set of lagged

\footnotetext{
${ }^{27}$ Apart from consistency with the model, the time-invariant version of the financial development variable is our preferred measure for several reasons. First, variation in the variable within countries over time may be driven by unobserved factors, which would create an endogeneity problem. Second, the other variables we use as regressors - external finance dependence and our proxy for the local input price - are time-invariant.

${ }^{28}$ We postulate in the model that the markup varies across countries only. If instead it varies over industries as well as countries, the product of an industry-level measure of complexity and our baseline country level measure is a natural one.

${ }^{29}$ The model's main results are derived while integrating over different possible levels of productivity across industries. Thus they hold unconditionally on productivity, i.e., we do not need to control for productivity empirically in order to test the model. However, we keep productivity as a control in the baseline because the target's productivity level plays a role in some theories of foreign M\&A discussed in the robustness section.

${ }^{30}$ Levchenko and Zhang (2016) use a structural Ricardian trade model and the share of different country-
} 
macroeconomic covariates that may be correlated with financial development and institutions and affect foreign acquisitions. In our baseline specifications, we control for real GDP and GDP per capita. In the robustness exercises, we include additional controls such as the change in the nominal exchange rate, the use of IMF credit and loans as a percentage of a country's quota, and the growth of real GDP. All variables relate to the target country. ${ }^{31}$ In the sensitivity analysis, we also use proxies for trade costs and industry characteristics (e.g., the capital-to-labor ratio and R\&D intensity). These are defined in the corresponding section as well as in section B.1 of the online appendix.

\subsection{Sample statistics}

In the baseline analysis, we aggregate the data by target sector, target country, and year. We therefore use the share of full acquisitions among foreign acquisitions, the average stake acquired by foreign acquirers, and the share of foreign acquisitions in total (foreign and domestic) acquisitions as the dependent variables. We do so because the model's predictions about these outcome variables are framed in terms of target countries' and sectors' characteristics. Moreover, our dataset does not include transaction-level covariates other than the size and type of acquisitions.

Table 2: Final sample statistics

\begin{tabular}{lcccccc}
\hline \hline & Obs. & Mean & S.D. & Q1 & Median & Q3 \\
\hline Share foreign acquisitions & & & & & & \\
Share full acquisitions (all) & 2224 & 0.46 & 0.40 & 0.00 & 0.44 & 1.00 \\
Share full acquisitions (foreign) & 1541 & 0.38 & 0.41 & 0.00 & 0.25 & 0.80 \\
Average fraction acquired (all) & 2224 & 0.40 & 0.38 & 0.00 & 0.33 & 0.67 \\
Average fraction acquired (foreign) & 2224 & 0.63 & 0.28 & 0.44 & 0.63 & 0.87 \\
Average fraction acquired (foreign. partial acq.) & 1541 & 0.62 & 0.30 & 0.38 & 0.60 & 0.95 \\
External finance dependence & 1172 & 0.39 & 0.21 & 0.24 & 0.38 & 0.51 \\
Private credit / GDP & 2224 & 0.30 & 0.26 & 0.15 & 0.21 & 0.45 \\
Anti-corruption index & 2224 & 0.65 & 0.38 & 0.33 & 0.62 & 1.10 \\
Technology relative to US & 2224 & -0.04 & 0.51 & -0.39 & -0.19 & 0.36 \\
GDP per capita & 2207 & 0.06 & 0.15 & 0.00 & 0.01 & 0.06 \\
Real GDP growth & 2224 & 9342.84 & 5661.32 & 4721.07 & 8324.20 & 11850.56 \\
\hline \hline
\end{tabular}

Source: Authors' calculations from Thomson Reuters SDC Platinum Mergers and Acquisitions database, World Bank, IMF and Rajan and Zingales (1998). Variables relative to foreign acquisition are averages computed from the SDC database, by target country, target industry, and year. The anti-corruption index comes from the World Bank Governance Indicators and is a measure of perceptions of corruption. Technology relative to the US is from Levchenko and Zhang (2016).

Table 2 contains statistics about the final sample. The average values for the dependent variables needed to test our main hypotheses are as follows. The share of full acquisitions among foreign acquisitions is $40 \%$ (for Hypotheses 1.a. and 1.b.); the average stake acquired by

industries in US imports to infer a measure of comparative advantage of these countries in different sectors by decade. These measures are interpreted by the authors as the productivity levels of particular country-industries relative to the same sectors in the US.

${ }^{31}$ The data are from the Penn World Tables, the IMF's International Financial Statistics, Taiwan's National Statistical Office, and the Central Bank of the Republic of China. We exclude the real interest rate because of data availability. Annual and quarterly real interest rate data are unavailable for several countries in the early years of the sample period. 
foreign acquirers excluding full acquisitions is 39\% (for Hypothesis 2); and the share of foreign acquisitions in all acquisitions is $46 \%$ (for Hypotheses 3.a. and 3.b.). When discussing the regression results we thus refer to changes in these dependent variables in percentage points. For example, we refer to a change in the share of full acquisitions from 0.10 to 0.20 as a 10 percentage point change.

The average level of the ratio of private credit to GDP is 0.65 , with the lower ratio being observed in Peru (0.17) and the highest in South Africa (1.11). The control-of-corruption data display important cross-country heterogeneity, with the worst-rated country being Indonesia (with an index of -0.8) and the best-rated Chile (with an index of 1.4). Finally, the countries in the sample experienced strong positive growth, on average, over the sample period.

We next turn to testing Hypotheses 1 to 3.

\subsection{Testing Hypothesis 1: The share of full foreign acquisitions}

Hypothesis 1 states that among foreign acquisitions, the share of full acquisitions is larger in target sectors more dependent upon external finance, in less financially developed target countries, and in target countries with a low local input price markup (Hypothesis 1.a). In addition, the effects of a low local input price and financial development are larger in financially dependent sectors (Hypothesis 1.b).

Hypothesis 1.a. Let us define $S_{i c t}^{F}$ as the share of full acquisitions in all foreign acquisitions taking place in target industry $i$, target country $c$ during year $t .^{32}$ The direct effect of external finance dependence is tested using the specification:

$$
S_{i c t}^{F}=\alpha_{1} \mathrm{EF}_{i}+\boldsymbol{\mu}_{c t}+\delta A_{i c}+\epsilon_{i c t}
$$

where $\mathrm{EF}_{i}$ represents the industry-specific measure of external finance dependence from Rajan and Zingales (1998). The model predicts that the estimates of $\alpha_{1}$ should be positive. Full foreign acquisitions are more likely in sectors that are more dependent upon external finance. Because the model predicts that full acquisitions take place in more productive industries, we control for technology using the measure of industry-level productivity relative to that of the United States from Levchenko and Zhang (2016) for each of the countries in the sample. We also include a full set of target country $\times$ year $\left(\boldsymbol{\mu}_{\boldsymbol{c} t}\right)$ fixed effects. The fixed effects are intended to account for cyclical macroeconomic conditions that may affect the foreign acquisitions, such as macroeconomic fundamentals, financial crises (e.g., the 1997-98 Asian financial crisis), or slowly evolving country characteristics such as barriers to FDI, financial development, or the quality of institutions. We therefore identify the effect of external finance dependence within country-year, across industries.

We estimate equation (4.1) and the rest of the specifications using a linear probability model, which handles better multiple fixed effects and interaction terms. We show later that the results are robust to the use of the nonlinear fractional logit estimator. The standard errors in these

\footnotetext{
${ }^{32} \mathrm{~A}$ full acquisition is defined as a $100 \%$ acquisition, as before. In the robustness analysis, we examine alternative thresholds for defining a full acquisition.
} 
and the other regressions discussed in this section are clustered at the target country $\times$ industry level. The online appendix reports the results using alternative levels of clustering.

The effect of country-specific characteristics is estimated using the specification:

$$
S_{i c t}^{F}=\alpha_{2} \mathrm{FD}_{c}+\alpha_{3} \operatorname{Markup}_{c}+\boldsymbol{\rho}_{\boldsymbol{i}}+\delta A_{i c}+\boldsymbol{\nu}_{\boldsymbol{t}}+\mathbf{C}_{\mathbf{c t}}^{\prime} \boldsymbol{\gamma}+\epsilon_{i c t}
$$

where $\mathrm{FD}_{c}$ and Markup $c$ are the measures of the level of financial development and the markup over the local input price, the average levels of the ratio of private credit-to-GDP, and the control-of-corruption index. We control for target sector $\left(\boldsymbol{\rho}_{\boldsymbol{i}}\right)$ and year $\left(\boldsymbol{\nu}_{\boldsymbol{t}}\right)$ fixed effects as well as for a set of lagged macroeconomic covariates (real GDP and GDP per capita) that may be correlated with $\mathrm{FD}_{c}$ and Markup $_{c}$ and affect foreign acquisitions $\left(\mathbf{C}_{\mathbf{c t}}^{\prime}\right)$. The model predicts that $\alpha_{2}<0$ and $\alpha_{3}>0$. Full foreign acquisitions are more likely in countries with low levels of financial development and low markups over local input prices.

Table 3: Determinants of full foreign acquisitions: baseline results

\begin{tabular}{|c|c|c|c|c|c|}
\hline \multirow{3}{*}{$\begin{array}{l}\text { Dep. var. } \\
\text { Test of }\end{array}$} & \multicolumn{2}{|r|}{$(2)$} & (3) & (4) & $(5)$ \\
\hline & \multicolumn{5}{|c|}{ Share full foreign acquisitions } \\
\hline & \multicolumn{3}{|c|}{ - Hypothesis 1.a - } & \multicolumn{2}{|c|}{ - Hypothesis 1.b - } \\
\hline External dependence & $\begin{array}{l}0.153^{a} \\
(0.052)\end{array}$ & & & & \\
\hline Average financial development & & $\begin{array}{c}-0.098^{b} \\
(0.041)\end{array}$ & $\begin{array}{l}-0.143^{a} \\
(0.043)\end{array}$ & & \\
\hline Control of corruption & & & $\begin{array}{l}0.094^{b} \\
(0.044)\end{array}$ & & \\
\hline External dep. $\times$ average fin. dev. & & & & $\begin{array}{l}-0.118 \\
(0.125)\end{array}$ & $\begin{array}{c}-0.333^{a} \\
(0.120)\end{array}$ \\
\hline External dep. $\times$ control of corruption & & & & & $\begin{array}{c}0.416^{a} \\
(0.071)\end{array}$ \\
\hline Tech. relative to US & $\begin{array}{c}0.120 \\
(0.096)\end{array}$ & $\begin{array}{c}0.067 \\
(0.088)\end{array}$ & $\begin{array}{c}0.038 \\
(0.083)\end{array}$ & $\begin{array}{c}0.047 \\
(0.111)\end{array}$ & $\begin{array}{c}0.102 \\
(0.112)\end{array}$ \\
\hline Observations & 1529 & 1529 & 1529 & 1529 & 1529 \\
\hline$R^{2}$ & 0.290 & 0.113 & 0.119 & 0.317 & 0.330 \\
\hline Macroeconomic Controls & No & Yes & Yes & No & No \\
\hline Year FE & Yes & Yes & Yes & No & No \\
\hline Target sector FE & No & Yes & Yes & Yes & Yes \\
\hline Target country $\times$ Year FE & Yes & No & No & Yes & Yes \\
\hline
\end{tabular}

Notes: ${ }^{c}$ significant at $10 \% ;{ }^{b}$ significant at $5 \% ;{ }^{a}$ significant at $1 \%$. OLS estimations. Standard errors clustered by target country $\times$ target industry. Estimations at the target country $\times$ target industry $\times$ year. These estimations are restricted to the sample of foreign acquisitions. External dependence target is the level of external finance dependence of the target sector from Rajan and Zingales (1998). Financial development is the average ratio of private credit over GDP over the period of the target country from the World Bank GFDD. Control of corruption index is the average country-level score of control of corruption from the WGI dataset. Macroeconomic controls include the lagged real GDP and GDP per capita, both in logs. Technology relative to the US is from Levchenko and Zhang (2016).

Columns (1) to (3) of Table 3 present the results. Column (1) shows the results of the estimation of equation (4.1) and columns (2) and (3) the results obtained for equation (4.2). In these regressions, we consider only foreign acquisitions and define full acquisitions as all acquisitions where the foreign acquirer purchases $100 \%$ of the target. 
The estimated coefficients associated with dependence on external finance reported in the first column of the table provide evidence in favor of the model's predictions. The share of full acquisitions in foreign acquisitions is positively related to dependence on external finance, and the estimate is statistically significant at the $1 \%$ level. Targets located in industries that have a greater reliance on external finance are more likely to be fully acquired by foreign firms, and the effect is quantitatively meaningful. The share of full foreign acquisitions is predicted to be 22 percentage points larger for the sector with the highest level of external finance dependence (professional and scientific equipment) compared with the sector that has the lowest level dependence on external finance (tobacco).

Columns (2) and (3) present the results on the role of cross-country differences in the level of financial development and institutional quality as drivers of full foreign acquisitions. Comparing column (2) with column (3) shows that the estimated coefficient associated with the average level of financial development becomes larger and more significant when we include the control-of-corruption index as a separate regressor. This difference points to the importance of considering both of these country characteristics simultaneously. In column (3), the estimated coefficient associated with financial development is negative - that is, higher levels of financial development are correlated with smaller shares of full acquisitions - and the coefficient is statistically significant at the $1 \%$ level. This finding matches what the model predicts. The positive coefficient estimate associated with the corruption index is also consistent with what the model predicts. Full acquisitions occur more frequently in countries with low markups over local input prices (i.e., low levels of corruption). The share of full acquisitions in all foreign acquisitions is 21 percentage points lower in the country with the lowest anti-corruption index (Indonesia) than in the least corrupt country (Chile) of the sample. In comparison, the difference in this share between the top and the bottom countries in terms of financial development (South Africa, for which the ratio is slightly above 1 , and Peru, for which the ratio is 0.17 ) is around 14 percentage points. These results help to explain why full acquisitions are seldom observed in countries that feature both developed financial markets and weak institutions. In our sample, Thailand is such a country, and the share of full acquisitions in foreign transactions is one of the lowest of the sample, at $19 \%$.

Finally, the technology variable exhibits a positive sign in all columns as expected, but its coefficient is not statistically significant at conventional levels. These regressions include either country $\times$ year fixed effects (col. 1) or controls for GDP and GDP per capita, both of which have estimated coefficients that are positive and highly significant. Most of the variation in the Levchenko and Zhang (2016) measure is observed across countries and is correlated with GDP and GDP per capita, so removing these variables from the regression restores the significance of the technology measure. ${ }^{33}$

Hypothesis 1.b. We now study whether the effect of financial development and markup over local input price on full foreign acquisitions are magnified in sectors with high external finance

\footnotetext{
${ }^{33}$ See section 5.6 for more discussion about the productivity variable.
} 
dependence. To do so, we include interaction terms in equation (4.1):

$$
S_{i c t}^{F}=\beta \mathrm{EF}_{i} \times \mathrm{FD}_{c}+\gamma \mathrm{EF}_{i} \times \operatorname{Markup}_{c}+\boldsymbol{\mu}_{\boldsymbol{c t}}+\boldsymbol{\rho}_{\boldsymbol{i}}+\epsilon_{i c t}
$$

The model predicts that $\beta<0$ and $\gamma>0$. Foreign acquisitions are less likely in financially developed countries and in countries with high levels of corruption, especially in financially dependent sectors. We include country $\times$ year $\left(\mu_{c t}\right)$ and sector $\left(\rho_{i}\right)$ fixed effects, which implies that only the coefficients on the interaction terms can be identified, as in Rajan and Zingales (1998). This specification is the cleanest one as it controls for unobserved country or sector characteristics that affect foreign M\&A. In the online appendix, we report results of specifications that do not include sector fixed effects in order to estimate the average effect of external finance dependence.

The results are shown in columns (4) and (5) of Table 3. Once again, it is important to control for the quality of institutions to obtain coefficient estimates on the interaction terms that are consistent with the model. Although the estimated coefficient on the interaction term $\mathrm{EF}_{i} \times \mathrm{FD}_{c}$ in column (4) has the negative sign that the model predicts, it is not statistically significant at conventional levels. But when the interaction term $\mathrm{EF}_{i} \times \operatorname{Markup}_{c}$ is included in the regression, the estimated coefficient associated with the interaction of dependence on external finance and financial development almost doubles in economic significance and becomes statistically significant at conventional levels. In addition, the positive coefficient estimate associated with the interaction term between dependence on external finance and institutional quality shows that higher quality institutions make it even more likely that domestic firms in external finance dependent sectors will be acquired fully by foreign investors.

Figure 4 depicts these results graphically. We estimate a specification akin to column (5) of Table 3 but without sector fixed effects. This specification enables us to estimate the average effect of external finance dependence. In Figure 4.a, we plot the estimated effect of external finance dependence, as a function of financial development, and holding the corruption index constant at its median value. While external dependence has a strong effect in financially underdeveloped countries, the estimates become statistically insignificant when the ratio of private credit over GDP exceeds 0.7. In the same vein, Figure 4.b shows that external finance matters roughly three times more in countries with the highest levels of control-of-corruption than in more corrupt countries.

Another way to gauge the quantitative implications of our results is shown in Figure 5. Here we plot the predicted change in the share of full acquisitions that would occur if all countries moved to the top level of financial development (Panel a) or control of corruption (Panel b) observed in our sample. Unlike the evidence presented earlier, which was reported in percentage points, the results in this figure are expressed in percentage changes of the shares - i.e., 0.1 means a 10 percent change in the shares. According to the figure, a country like China, for instance, would experience a doubling in the share of full acquisitions if it were to reach the level of control-of-corruption of Chile. 
Figure 4: Effect of external dependence on full acquisitions

(a) w.r. to financial development

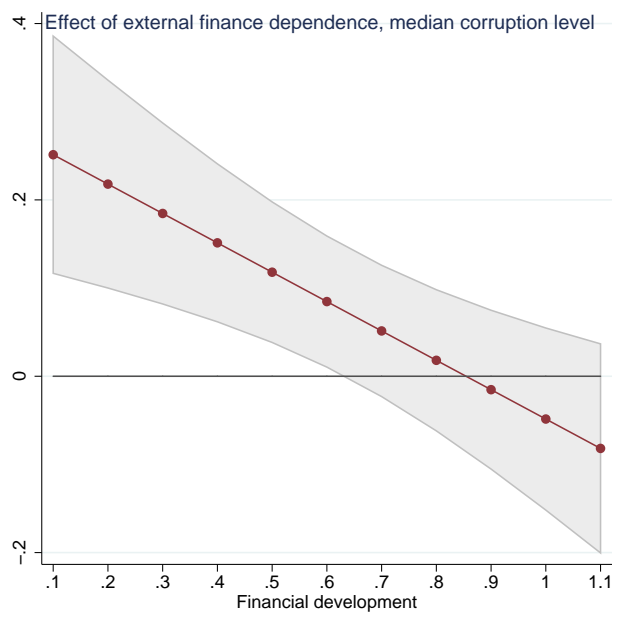

(b) w.r. to control-of-corruption

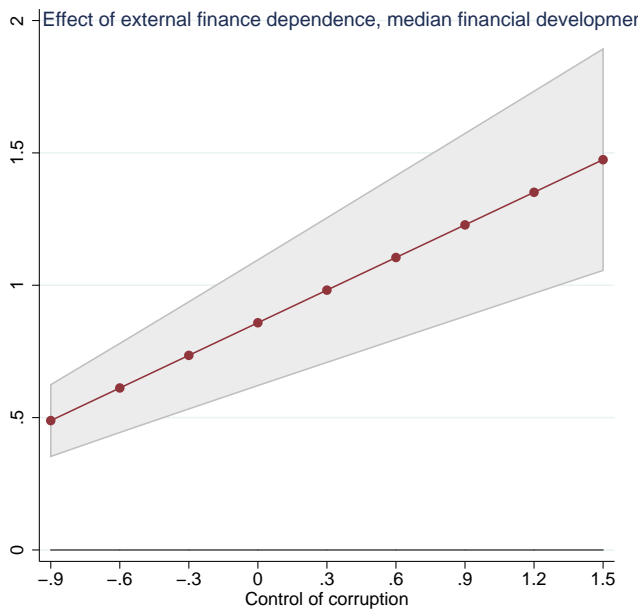

Note: These figures present the effect of external finance dependence on the share of full foreign acquisitions, for different levels of financial development and the control-of-corruption index. Figure (a) assumes a median level of level of corruption; Figure (b) assumes a median level of financial development. The estimated effects are obtained from a specification similar to column (5) of Table 3 , except that sector dummies are not included to allow the effect of external finance dependence to be identified. Grey area represent $90 \%$ confidence bands.

Figure 5: Counterfactuals

(a) Increase of financial development

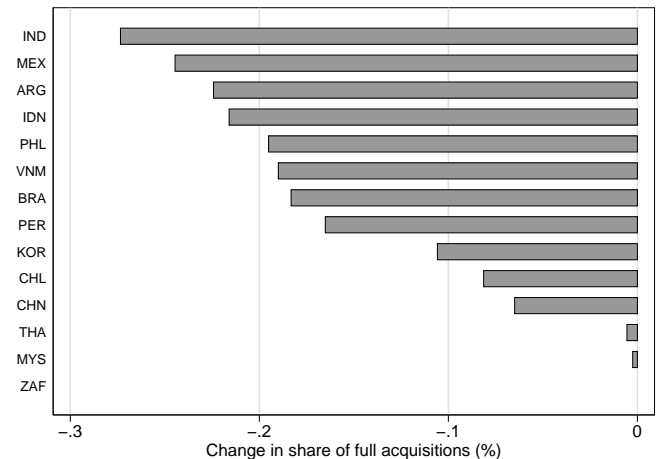

(b) Increase in control-of-corruption

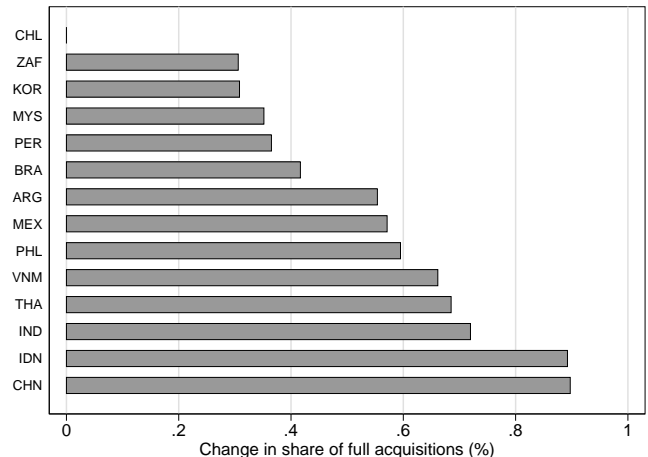

Note: These figures represent the effect of increases in financial development and the control-of-corruption index on the share of full foreign acquisitions. Figure (a) compares the predicted share of full foreign acquisitions if all countries had the highest value of financial development in the sample (South Africa, 1.04); Figure (b) compares the predicted share of full foreign acquisitions if all countries had the highest value of control-of-corruption in the sample (Chile, 1.42). The estimated effects are obtained from a specification similar to column (5) of Table 3 , except that sector dummies are not included to allow the effect of external finance dependence to be identified. We first predict the share of full acquisitions with the actual value of financial development/control-of-corruption; then with the counterfactual value; then we average over the period by country and compute the percentage change in the predicted share.

\subsection{Testing Hypothesis 2: The size of partial foreign acquisitions}

Hypothesis 2 predicts that among partial foreign acquisitions, the average share acquired is not sensitive to local input price markup and is weakly related to external finance dependence and financial development. To test these predictions, we confine the analysis to partial foreign acquisitions, i.e., transactions for which the share acquired by foreign investors is strictly larger than 0 and less than 1. We replace the dependent variable in equations (4.1), (4.2) and (4.3) with $S_{i c t}^{P}$, the average share acquired in an industry-country-year unit.

Table 4 shows the results obtained when projecting the size of the stake acquired on the 
financial factors and institutional quality index suggested by the model. The structure is the same as in Table 4: We first consider the effect of external finance dependence in column (1), before analyzing the effect of country characteristics - financial development and corruption in columns (2) and (3). Columns (4) and (5) look at the interaction between external finance dependence and country characteristics, controlling for sector and country unobservables.

Table 4: Determinants of the size of partial foreign stake: baseline results

\begin{tabular}{|c|c|c|c|c|c|}
\hline \multirow[b]{2}{*}{$\begin{array}{l}\text { Dep. var. } \\
\text { Test of }\end{array}$} & (1) & $(2)$ & $(3)$ & (4) & (5) \\
\hline & \multicolumn{5}{|c|}{$\begin{array}{l}\text { Size of foreign stake (only partial acquisitions) } \\
\qquad \text { Hypothesis } 2\end{array}$} \\
\hline External dependence & $\begin{array}{c}0.028 \\
(0.024)\end{array}$ & & & & \\
\hline Average financial development & & $\begin{array}{c}-0.053^{a} \\
(0.018)\end{array}$ & $\begin{array}{l}-0.039^{c} \\
(0.021)\end{array}$ & & \\
\hline Control of corruption & & & $\begin{array}{l}-0.033^{c} \\
(0.019)\end{array}$ & & \\
\hline External dep. $\times$ average fin. dev. & & & & $\begin{array}{l}-0.032 \\
(0.061)\end{array}$ & $\begin{array}{c}-0.011 \\
(0.060)\end{array}$ \\
\hline External dep. $\times$ control of corruption & & & & & $\begin{array}{l}-0.049 \\
(0.056)\end{array}$ \\
\hline Tech. relative to US & $\begin{array}{l}-0.058 \\
(0.078)\end{array}$ & $\begin{array}{c}0.022 \\
(0.053)\end{array}$ & $\begin{array}{c}0.036 \\
(0.054)\end{array}$ & $\begin{array}{l}-0.031 \\
(0.084)\end{array}$ & $\begin{array}{l}-0.037 \\
(0.085)\end{array}$ \\
\hline Observations & 1163 & 1163 & 1163 & 1163 & 1163 \\
\hline$R^{2}$ & 0.256 & 0.099 & 0.102 & 0.308 & 0.309 \\
\hline Macroeconomic Controls & No & Yes & Yes & No & No \\
\hline Year FE & Yes & Yes & Yes & No & No \\
\hline Target sector FE & No & Yes & Yes & Yes & Yes \\
\hline Target country $\times$ Year FE & Yes & No & No & Yes & Yes \\
\hline
\end{tabular}

Notes: ${ }^{c}$ significant at $10 \% ;^{b}$ significant at $5 \% ;^{a}$ significant at $1 \%$. OLS estimations. Standard errors clustered by target country $\times$ target industry. Estimations at the target country $\times$ target industry $\times$ year. These estimations are restricted to the sample of foreign acquisitions. External dependence target is the level of external finance dependence of the target sector from Rajan and Zingales (1998). Financial development is the average ratio of private credit over GDP over the period of the target country from the World Bank GFDD. The control-of-corruption index is the average country-level score of control of corruption from the WGI dataset. Macroeconomic controls include the lagged real GDP and GDP per capita, both in logs. Technology relative to the US is from Levchenko and Zhang (2016).

External financial dependence and financial development have the expected signs, but they are generally statistically insignificant or significant only at the $10 \%$ level only (columns (1) and (3)). The interaction between financial development and external finance dependence turns out to be insignificant, as do the interaction between the corruption index and external finance dependence. Taken together, these results match the model's predictions. The markup over the local input price should have no effect and hence the control-of-corruption index as well as its interaction with external finance dependence should have insignificant coefficients. The model also predicts that financial factors should have an effect only in some sectors, depending on the technological importance of the local input. On average, the effect of such factors on partial acquisitions should therefore be weaker than that for full acquisitions, which is what table 4 suggests. 


\subsection{Testing Hypothesis 3: The share of foreign acquisitions}

The last testable hypothesis of the model relates the probability of foreign acquisitions to the direct effects of financial factors and local input prices and the interaction between the two variables. More precisely, Hypothesis 3.a. predicts that foreign acquisitions occur more frequently in external finance dependent sectors, in countries with lower levels of financial development, and in countries that have a lower local input price markup; and Hypothesis 3.b. states that both the effects of domestic financial development and local input prices are magnified in more external finance dependent sectors. These predictions are implied when one combines the effect on full and partial foreign acquisitions - which obviously comprise the totality of foreign acquisitions - of financial factors and local input prices.

To test these predictions, we consider both domestic and foreign acquisitions and use as a dependent variable in equations (4.1), (4.2) and (4.3) the share of foreign acquisitions among all acquisitions taking place in a given country, sector, and year. We would ideally like to use the ratio of the number of foreign acquisitions over the total number firms that can be acquired, but we do not have time-varying information on the number of firms by market and sector. This is a limitation of the exercise presented in this section and the main reason why we restrict our attention to Hypotheses 1 and 2 in the robustness exercises.

Table 5: Determinants of overall foreign acquisitions: baseline results

\begin{tabular}{|c|c|c|c|c|c|}
\hline \multirow[b]{2}{*}{$\begin{array}{l}\text { Dep. var. } \\
\text { Test of }\end{array}$} & \multirow{2}{*}{\multicolumn{5}{|c|}{$\begin{array}{l}(1) \quad(2) \\
\text { Share foreign acquisitions in all acquisitions }\end{array}$}} \\
\hline & & & & & \\
\hline External dependence & $\begin{array}{l}0.153^{a} \\
(0.032)\end{array}$ & & & & \\
\hline Average financial development & & $\begin{array}{l}-0.292^{a} \\
(0.029)\end{array}$ & $\begin{array}{l}-0.281^{a} \\
(0.037)\end{array}$ & & \\
\hline Control of corruption index & & & $\begin{array}{c}-0.024 \\
(0.043)\end{array}$ & & \\
\hline External dep. $\times$ average fin. dev. & & & & $\begin{array}{c}-0.217^{a} \\
(0.081)\end{array}$ & $\begin{array}{c}-0.231^{b} \\
(0.093)\end{array}$ \\
\hline External dep. $\times$ control of corruption & & & & & $\begin{array}{c}0.022 \\
(0.075)\end{array}$ \\
\hline Tech. relative to US & $\begin{array}{l}-0.027 \\
(0.064)\end{array}$ & $\begin{array}{l}-0.086 \\
(0.073)\end{array}$ & $\begin{array}{l}-0.077 \\
(0.074)\end{array}$ & $\begin{array}{c}0.031 \\
(0.064)\end{array}$ & $\begin{array}{c}0.034 \\
(0.065)\end{array}$ \\
\hline Observations & 2207 & 2207 & 2207 & 2207 & 2207 \\
\hline$R^{2}$ & 0.338 & 0.142 & 0.142 & 0.357 & 0.357 \\
\hline Macroeconomic Controls & No & Yes & Yes & No & No \\
\hline Year FE & Yes & Yes & Yes & No & No \\
\hline Target sector FE & No & Yes & Yes & Yes & Yes \\
\hline Target country $\times$ Year FE & Yes & No & No & Yes & Yes \\
\hline
\end{tabular}

Notes: ${ }^{c}$ significant at $10 \% ;^{b}$ significant at $5 \% ;^{a}$ significant at $1 \%$. OLS estimations. Standard errors clustered by target country $\times$ target industry. Estimations at the target country $\times$ target industry $\times$ year. External dependence target is the level of external financial dependence of the target sector from Rajan and Zingales (1998). Financial development is the average ratio of private credit over GDP over the period of the target country from the World Bank GFDD. The control-of-corruption index is the average country-level score of control of corruption from the WGI dataset. Macroeconomic Controls include the lagged real GDP and GDP per capita, both in logs. Technology relative to the US is from Levchenko and Zhang (2016). 
Table 5 presents the results. As before, we sequentially consider external finance dependence (col. (1)), country-specific factors (cols. (2) and (3)) and their interaction (cols. (4) and (5)). The estimated coefficients associated with dependence on external finance reported in the first column of the table provide evidence supporting the model's predictions. The coefficient is precisely estimated and statistically significant at the $1 \%$ level. The effect is quantitatively similar to the one found in Table 3. Moving from the least to the most external finance dependent sector raises the share of foreign acquisitions (out of the total number of acquisitions) by 22 percentage points. In conjunction with the results for the sample of partial and full acquisitions reported in Table 3 and 4, this evidence underscores the economic importance of dependence on external finance as a determinant of foreign acquisitions.

Columns (2) and (3) report the results of the regressions that relate the share of foreign acquisitions to cross-sectional differences in the average levels of financial development and the control-of-corruption index. The probability of a foreign acquisition is negatively related to crosscountry differences in financial development, and the coefficient estimates in both regressions are statistically significant at the $1 \%$ level. Foreign acquisitions are less likely in countries with more developed financial sectors. Compared to the least financially developed country (Peru), the share of foreign acquisitions is predicted to be 27 percentage points lower for targets located in the most financially developed country (South Africa). By contrast, in column (3) the coefficient on the control-of-corruption index is positive but statistically insignificant. Finally, the results shown in columns (4) to (5) are also more supportive of the role of financial factors than they are for corruption.

The evidence presented in this subsection favors the substantive predictions of Hypothesis 3 regarding the relationship between the probability of a foreign acquisition, the target's dependence on external finance, the country's level of financial dependence, and the interaction between the two financial factors. It is less supportive of the prediction that the probability of a foreign acquisition is positively associated with strong institutions, which make procuring the local input less costly for the foreign acquirer. A conclusion that can be drawn from these results is that, since local input prices have a different effect on partial and full acquisitions, pooling all types of transactions together is problematic as it masks these different dynamics. An important caveat is that we do not have the perfect data - time-varying information on the number of firms by market and sector - to study the determinants of the overall probability of foreign acquisitions.

\section{$5 \quad$ Additional results and sensitivity analysis}

In this section we test the sensitivity of our empirical tests of Hypotheses 1 and 2 to several modifications of the baseline regression model. Most of the tables are relegated to section $\mathrm{C}$ of the online appendix, where we provide further discussion. For reasons explained earlier, we do not conduct these checks on the tests of hypothesis 3 .

\subsection{Foreign ownership restrictions and sample sensitivity}

Our analysis has abstracted from restrictions on the share of foreign ownership in the sample of 
countries. If such restrictions exist and if their presence is correlated with our variables of interest - e.g., if ownership restrictions tend to vary with financial development or corruption levels - our estimates would be biased. ${ }^{34}$ Because a comprehensive dataset on foreign ownership restrictions at the country-sector-year level does not exist, we have looked for sector specific information for each country of our sample separately. Section B.2 of the online appendix summarizes the findings. It appears that ownership restrictions are found mostly outside manufacturing (in service sectors, or in primary goods such are resource extraction) and that they are applied by few countries in our sample. Printing and publishing is the only sub-sector that regularly witnesses significant restrictions (in about half of the countries included in our sample). Among our countries, only four - China, Vietnam, India and Malaysia - impose restrictions in specific sectors other than manufacturing. Given that we concentrate on manufacturing, we therefore believe that such FDI restrictions are unlikely to drive our results.

We did, however, conduct a series of additional robustness tests, presented and discussed in more detail in sections C.1, C.2 and C.3 of the online appendix. First, we dropped from the sample China and Vietnam, the two countries with the most significant number of restrictions, as well as the printing and publishing subsectors. The results, presented in Tables A.5 and A.6 are close to our baseline estimates. Second, we tried to identify barriers de facto from our data. More precisely, we have dropped from our sample all the 2-digit sector $\times$ country combinations for which we observe at least one 4 digit subsector where the share acquired by foreign firms is never $100 \%{ }^{35}$ Again the results were similar (Tables A.7 and A.8). Third, we control for interactions terms between external dependence and country-wide measures of FDI restrictions in regressions that include country and sectors fixed effects. The results are presented in Table A.9 and are consistent with our baseline estimates.

Finally, we perform two broader robustness exercises. In section C.2 we re-ran our estimates on 1,000 random samples in which we keep only $75 \%$ of the observations (sector $\times$ country $\times$ year) of our initial sample. We show that the estimates are centered around our baseline estimate. In the same vein, in section C.3, we dropped each country, sector or year of the sample sequentially to check that the results are not driven by particular countries, sectors or time periods. The results are extremely stable across samples. These different tests strongly suggest that (i) FDI restrictions in specific sectors or countries do not drive our results; and (ii) more generally, our results are not sensitive to the sample of countries, sectors or years that we use. $^{36}$

\subsection{Omitted variables and alternative theories of FDI}

Causal identification in our baseline estimations may be undermined by the existence of omitted variables: Factors affecting the size of foreign acquisitions and correlated with external

\footnotetext{
${ }^{34}$ This problem would arise if, for example, the restrictions varied at the country-industry-year level, so that they are not included in the fixed effects (see, for example, Sheng and Yang, 2016).

${ }^{35}$ Our de facto measure is conceptually analogous, for example, to de facto measures of financial (or trade) integration that use ratios of actual foreign assets (or trade) to GDP. We use 4 digit subsectors to identify possible restrictions because almost all sectors at the 2 digit level have at least one $100 \%$ acquisition.

${ }^{36}$ In Table A.10 of the online appendix C.3, we replicate the results of columns (2)-(3) of the baseline Tables on the sample containing all sectors, i.e. non-manufacturing as well as manufacturing. We cannot run the other regressions on that sample because the external finance dependence data is only available for manufacturing sectors.
} 
dependence, financial development, or institutions. Although the model omits other possible determinants of the ownership structure of inward FDI to emerging markets, theories of FDI have proposed alternative explanations for cross-border capital flows. While they are not necessarily directly related to foreign M\&A or the size of the stake acquired, they may still affect our estimates to some extent. The baseline regressions control for country-industry productivity and GDP per capita and thus already account for the "cream-skimming" hypothesis — namely, that foreign acquirers generally purchase more productive firms (see Razin and Sadka, 2007).

An alternative explanation that we do not account for in the baseline regressions is the proximity-concentration theory of horizontal FDI (see e.g. Krugman, 1983), which predicts that FDI is more likely in industries associated with higher variable trade costs (see Brainard, 1997) and located close to demand. When trade costs are higher, foreign firms optimally choose to circumvent them in order to take advantage of economies of scale. To control for proximityconcentration tradeoffs, we use data on average applied tariffs at the target country and two-digit SIC industry level obtained from the World Bank's World Integrated Trade Solution database, as well as a sector-specific measure of economies of scale from Antràs (2003). We also include a measure of market potential, at the country-industry level, from Mayer (2008).

A second set of theories explains vertical FDI based on locational advantages in emerging markets caused by lower factor prices (see Markusen, 1984; Helpman and Krugman, 1985, among others). To control for this type of locational advantage, we include a measure of target-sector labor intensity, the capital-labor ratio at the industry level (Antràs, 2003).

A third explanation is given by the incomplete-contracting, property-rights theory of the boundaries of multinational corporations. Antràs (2003) shows that incomplete contracts and a preference for variety explains the fact that the share of intrafirm imports in total U.S. imports is higher for more capital-intensive exporting industries. His model also pins down the boundaries of the international firm and predicts that FDI is more likely in capital-intensive industries. In addition to the capital-labor ratio at the industry level, Antràs (2003) uses as a control variable the research and development (R\&D) expenditures as a fraction of sales. This is especially important for our model as this sector characteristic may be correlated with dependence on external finance. It is possible, for example, that dependence on external finance proxies for technologically advanced industries in which developed market firms might have an advantage. We also control for partially incomplete contracting explanations (Antràs and Helpman, 2004, Nunn and Trefler, 2013) by including the sector-specific share of inputs that are relationshipspecific from Nunn (2007), and controlling for sector-specific "routineness" of tasks, which has been argued to be another source of contractual frictions by Costinot et al. (2011).

Finally, as Asia makes up a large part of our sample, it is also possible that the probability of a foreign acquisition depends on whether the industry supplies intermediate goods to firms based in developed markets, as many Asian companies do. To control for this possibility, we use the measure of upstreamness of industries computed by Chor et al. (2012) as an additional 
Table 6: Robustness: omitted variables and alternative theories

\begin{tabular}{|c|c|c|c|c|c|c|}
\hline \multirow[b]{2}{*}{ Dep. var. } & $(1)$ & $(2)$ & $\overline{(3)}$ & $(4)$ & $(5)$ & $(6)$ \\
\hline & \multicolumn{3}{|c|}{ Full acq. } & \multicolumn{3}{|c|}{ Frac. acq. (partial) } \\
\hline External financial dependence & $\begin{array}{c}0.159^{c} \\
(0.086)\end{array}$ & & & $\begin{array}{c}0.042 \\
(0.044)\end{array}$ & & \\
\hline Average financial development & & $\begin{array}{l}-0.145^{a} \\
(0.043)\end{array}$ & $\begin{array}{l}-0.200^{a} \\
(0.044)\end{array}$ & & $\begin{array}{l}-0.043^{b} \\
(0.021)\end{array}$ & $\begin{array}{l}-0.051^{b} \\
(0.022)\end{array}$ \\
\hline Control of corruption & & $\begin{array}{c}0.093^{b} \\
(0.047)\end{array}$ & $\begin{array}{c}0.113^{b} \\
(0.047)\end{array}$ & & $\begin{array}{l}-0.032^{c} \\
(0.019)\end{array}$ & $\begin{array}{l}-0.032 \\
(0.021)\end{array}$ \\
\hline $\mathrm{K} / \mathrm{L}$ & $\begin{array}{l}-0.067 \\
(0.080)\end{array}$ & & & $\begin{array}{c}0.049 \\
(0.053)\end{array}$ & & \\
\hline R\&D/Sales & $\begin{array}{c}0.447 \\
(1.714)\end{array}$ & & & $\begin{array}{c}0.922 \\
(1.080)\end{array}$ & & \\
\hline Scale & $\begin{array}{l}-0.047 \\
(0.041)\end{array}$ & & & $\begin{array}{c}-0.056^{b} \\
(0.028)\end{array}$ & & \\
\hline Relationship specificity & $\begin{array}{r}-0.463^{a} \\
(0.151)\end{array}$ & & & $\begin{array}{l}-0.130 \\
(0.092)\end{array}$ & & \\
\hline Routineness & $\begin{array}{l}-0.543^{c} \\
(0.326)\end{array}$ & & & $\begin{array}{c}-0.062 \\
(0.235)\end{array}$ & & \\
\hline Upstreamness & $\begin{array}{l}-0.108^{b} \\
(0.049)\end{array}$ & & & $\begin{array}{l}-0.010 \\
(0.027)\end{array}$ & & \\
\hline $\ln ($ tariff +1$)$ & $\begin{array}{l}-0.052 \\
(0.044)\end{array}$ & $\begin{array}{l}-0.052 \\
(0.041)\end{array}$ & $\begin{array}{l}-0.058 \\
(0.044)\end{array}$ & $\begin{array}{c}-0.024 \\
(0.025)\end{array}$ & $\begin{array}{l}-0.042^{b} \\
(0.018)\end{array}$ & $\begin{array}{l}-0.051^{b} \\
(0.020)\end{array}$ \\
\hline ln market potential & $\begin{array}{c}0.040^{a} \\
(0.012)\end{array}$ & $\begin{array}{l}-0.048^{a} \\
(0.018)\end{array}$ & $\begin{array}{c}0.023 \\
(0.024)\end{array}$ & $\begin{array}{c}0.011 \\
(0.008)\end{array}$ & $\begin{array}{c}-0.029^{a} \\
(0.008)\end{array}$ & $\begin{array}{l}-0.027^{b} \\
(0.013)\end{array}$ \\
\hline Tech. relative to the U.S. & $\begin{array}{c}0.081 \\
(0.112)\end{array}$ & $\begin{array}{c}0.037 \\
(0.088)\end{array}$ & $\begin{array}{c}0.140 \\
(0.140)\end{array}$ & $\begin{array}{l}-0.040 \\
(0.091)\end{array}$ & $\begin{array}{c}0.009 \\
(0.057)\end{array}$ & $\begin{array}{l}-0.004 \\
(0.068)\end{array}$ \\
\hline Observations & 1284 & 1515 & 1401 & 968 & 1149 & 1058 \\
\hline$R^{2}$ & 0.336 & 0.126 & 0.152 & 0.314 & 0.116 & 0.121 \\
\hline Macro Controls & No & Yes & Yes & No & Yes & Yes \\
\hline Macro Controls (extended) & No & No & Yes & No & No & Yes \\
\hline Sector FE & No & Yes & Yes & No & Yes & Yes \\
\hline Year FE & No & Yes & Yes & No & Yes & Yes \\
\hline Target country $\times$ Year FE & Yes & No & No & Yes & No & No \\
\hline
\end{tabular}

Notes: ${ }^{c}$ significant at $10 \% ;{ }^{b}$ significant at $5 \% ;{ }^{a}$ significant at $1 \%$. OLS estimations. Standard errors clustered by target country $\times$ target industry. Estimations at the target country $\times$ target industry $\times$ year. The dependent variable is: in column (1) and (2), the share of full acquisitions among foreign acquisitions; in columns (3) and (4), the average fraction acquired among partial foreign acquisitions. Financial development is the level of private credit of GDP of the target country, averaged over the period. The control-of-corruption index is the average country-level score of control of corruption from the World Bank. External dependence target is the level of external financial dependence of the target sector from Rajan and Zingales (1998). Macro controls include the lagged real GDP and GDP per capita, both in logs. Extended macro controls include the change in the nominal exchange rate, the use of IMF credit and loans as a percentage of a country's quota and the growth of real GDP. Technology relative to the US is from Levchenko and Zhang (2016). See the main text for details about the other control variables.

covariate. $^{37}$

The results are summarized in Table 6 . We consider sequentially the share of full acquisi-

\footnotetext{
${ }^{37}$ In addition to these explanations, there are theories of horizontal FDI with firm heterogeneity that relate the distribution of industry productivity in the source country to the decision to locate production abroad (see e.g. Helpman et al., 2004, Nocke and Yeaple, 2007, or Nocke and Yeaple, 2008) or to the degree of intermediation (Bernard et al., 2008). As the principal focus of our analysis is the characteristics of target firms in emerging markets that make them more likely to be acquired by a foreign firm, the dispersion of productivity or other source-country variables are not relevant to the central point of this paper; hence we do not consider these determinants in the empirical exercise.
} 
tions (col. 1-3) and the size of partial acquisitions (col. 4-6). Columns (1) and (3) estimate the effect of external finance dependence. Given that we control for country fixed effects in these estimations, omitted variables must be sector or sector-country specific. Accordingly, we include as additional controls the capital-to-labor ratio of the target industry, the ratio of R\&D expenditures over sales and the extent of economies of scale, all from Antràs (2003); the degree of relationship specificity from (Nunn, 2007); the degree of task routineness from Costinot et al. (2011); a measure of upstreamness from Chor et al. (2012); measures of tariff and market potential; and the measure of technology included in the baseline regressions. The first two variables are sector-specific, and the last three vary by target country and sector. Despite the inclusion of all these variables and the limited degrees of freedom - the external finance dependence variable has only twenty observations - our results remain quite stable. External dependence remains a statistically significant predictor (at the $10 \%$ level) of full foreign acquisitions, and the effect remains quantitatively stable. In the case of partial foreign acquisitions, the magnitude of the coefficient on external finance dependence increases slightly but remains statistically insignificant. In columns (2) and (5), we consider country-specific variables, financial development, and the control-of-corruption index. As before, we include tariffs, market potential, and the technology variable. In columns (3) and (6) we also include several additional macroeconomic aggregates at the country level, which capture short-term factors affecting FDI, such as aggregate liquidity (see Aguiar and Gopinath, 2005; Alquist et al., 2016), business cycle variations (Erel et al., 2012) or exchange rate changes (Froot, 1991). The results are reinforced compared to our baseline. Financial development affects the share of full acquisitions, but also (at the 5\% confidence level) the size of foreign stakes. Control-of-corruption only affects full acquisitions. Overall, these results confirm the conclusions from the baseline regressions: Financial factors affect both full and partial acquisitions, although the effect is limited in the latter case. On the other hand, institutions only affect the share of full acquisitions.

Interestingly, relationship-specificity is found to have a negative effect on the share of full acquisitions. This variable represents the share of complex inputs, i.e. the degree of product differentiation on the input side based on classification in Rauch (1999). One could interpret this variable as an alternative proxy for markups over input costs; this interpretation would be in line with our theory. We return to this point in section 5.5.

\subsection{Full acquisition threshold}

We have assumed thus far that an acquisition is a "full" one when the share acquired is $100 \%$. In the model, a full acquisition is essentially the purchase of rights to produce using the technology of the domestic firm. In practice, the threshold at which this occurs may be lower than $100 \%$. This issue is an important one for results on the markup over the local input price (i.e., the control-of-corruption index), which is predicted to affect only the likelihood of full foreign acquisitions.

We replicate the baseline regressions of Table 3, column (3) using different thresholds for "full" acquisitions. The results are depicted in Figure 6. Panel (a) shows the coefficients and confidence bands obtained for the financial development variable, as a function of the threshold; panel (b) plots the same information for the control-of-corruption variable. Each coefficient is 
(a) Effect of financial development

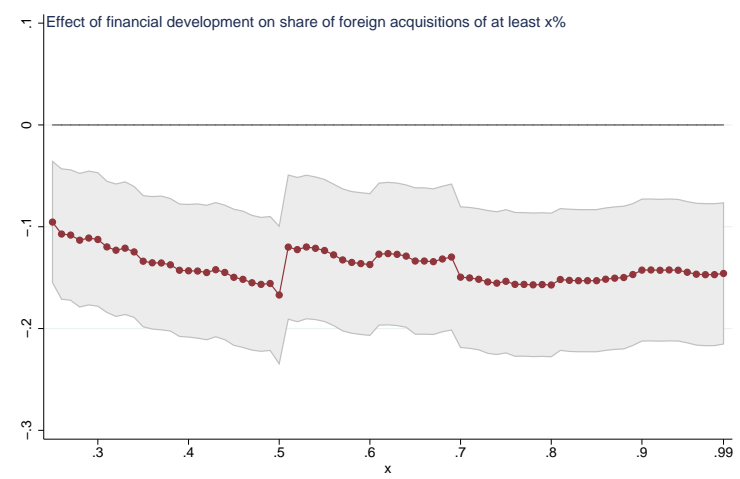

(b) Effect of control of corruption

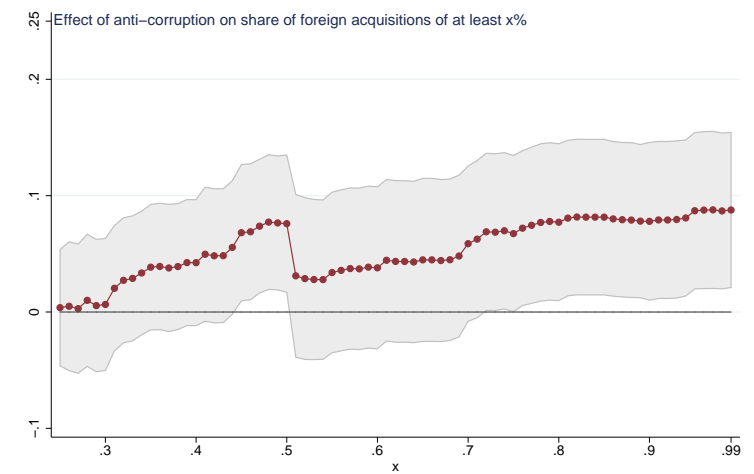

Note: These figures plot the effect of financial development and of the anti-corruption index on the probability of full acquisitions. The threshold for full acquisitions varies along the horizontal axis. The regressions are akin to column (3) of Table 3, except that the share of full acquisitions (dependent variable) is computed according to the corresponding threshold. Grey area represent $90 \%$ confidence bands.

obtained from a separate regression, where the dependent variable is the share of full acquisitions computed according to the corresponding threshold, which varies between 25 and 100\%. The effect of financial development does not vary with the chosen threshold. This finding was expected because financial development is also predicted to affect the share acquired. On the other hand, only large thresholds lead to significant estimates in the case of the control of corruption variable. It becomes significant at $50 \%$, which is the threshold where a large number of acquisitions take place, as shown in Figure 1, and again at $75 \%$ or more. In section C. 4 of the online appendix we present regressions akin to the baseline Table 3, except that the threshold is either $75 \%$ (Table A.11) or 50\% (Table A.12).

\subsection{Measurement and endogeneity of country-level variables}

The benchmark results use a period-average measure of the country-specific variables. This modeling choice has two drawbacks. First, it may not accurately reflect the contemporaneous level of these variables. Second, endogeneity could still be present. In particular, countries receiving more FDI in the manufacturing sector may also receive more FDI in the financial and banking sectors, which would in turn affect the level of financial development. ${ }^{38}$ Likewise, corruption could be affected by aggregate foreign ownership.

To address these issues, we perform several additional exercises that appear in the online appendix C.5. First, in Table A.13 we use either a time-varying measure rather than the country average or a time-invariant pre-period measure (i.e., the average private credit to GDP ratio over the 1985-1989 period, the five years before the start of our sample period). Second, in Tables A.14 and A.15 we instrument current period financial development or the corruption index with pre-period values ${ }^{39}$, or we directly control for the number of foreign acquisitions in the financial

\footnotetext{
${ }^{38}$ Endogeneity stemming from this underlying relationship would arguably generate a positive correlation between FDI and financial development - the opposite of what we find. In terms of omitted variables, if FDI flows to any two sectors - manufacturing and finance in this case - are positively correlated, and FDI in the financial sector is correlated positively with financial development, then our (negative) estimated coefficient on the financial development indicator represents a lower bound for the effect of financial development on acquisitions.

${ }^{39}$ The control-of-corruption index is only available from 1996 onward. For this reason, when instrumenting this
} 
sector over the period in the regressions. In all cases the results are similar.

In section C.6, we assess the robustness of the cross-effect of external finance dependence and financial development. We estimate the effect of external finance dependence on subsamples defined according to the level of financial development of the origin and target countries. In Table A.16, we show that the effect of external finance dependence is only significant when the level of financial development of the target country is lower than that of the acquirer country, which is the case we consider in the model. In Table A.17, we show that the effect of external finance dependence is significantly stronger in the least financially developed countries of the sample, using either the sample median or first quartile as cutoffs.

\subsection{Markup over input costs}

In section C.7 of the online appendix, we use alternative proxies for the markup over the local input price. In Table A.18 we use different institutional measures - an anti-corruption measure from Transparency International, an indicator of the quality of government from the International Country Risk Guide (2013), and an index of business freedom from the World Bank's Doing Business study. We focus on the results for full acquisitions because that sample is the one for which the model predicts an effect of the markup over the local input price. In Table A.19 we use as an alternative measure the industry-specific level of differentiation of inputs: the level of relationship specificity of inputs computed by Nunn (2007) based on the Rauch (1999) industry classification. Interpreting a high degree of input differentiation as a high input price markup, we expect this variable to be negatively related to the probability of a full acquisition and that there is no effect on the size of partial acquisitions. Likewise, the negative effect of high input differentiation should be weaker in countries characterized by a low corruption level or stronger institutions in general. We find that the non-interacted input complexity variable has a negative sign with a $p$-value of 0.16 . Controlling for other sector-specific variables, the estimated coefficient becomes larger and statistically significant (Table 6 above). Finally, the estimated coefficients of the variable interacted with our anti-corruption index and rule of law also have the predicted positive signs and are significant at the $1 \%$ or $5 \%$ levels.

\subsection{Productivity}

Our baseline regressions control for sector-country productivity. This variable, however, is not theoretically needed, as discussed briefly in section 3.2 and in more detail in the appendix, where we consider a simplified version of the model with $A_{i c}=1$. Moreover, productivity as it is observed in the data may be affected by credit constraints or inputs markups (i.e., we do not observe the true $A_{i c}$ ). These measurement issues could complicate the identification of our coefficients of interest. In the online appendix C.8, we show that the main results are largely unchanged when productivity is dropped from the regressions.

\subsection{Dynamic acquisitions}

The model and empirical tests are inherently static. In principle, if information were incomplete, firms could start by acquiring partially their target before potentially switching to full ownership,

variable we use its 1996 value and restrict the sample to years 1997 onwards. 
as explored in recent papers such as Bircan (2017). We consider this possibility in the online appendix section C.9. We control for the fraction owned by the acquirers before the acquisition takes place (Table A.23) or include a dummy variable that equals 1 if the acquirer already owned part of the target before in the full acquisitions regressions (Table A.24). In these tables, the dependent variable is a dummy for full acquisitions, defined as the acquirer owning $100 \%$ of the target after the acquisitions. We find that owning a fraction of the target before increases the likelihood of a full acquisition. However, our coefficients of interest are largely unaffected, which suggests that our explanation is orthogonal to this alternative, dynamic mechanism.

\subsection{Econometric issues}

Specification. The baseline regressions in sections 4.4 and 4.5 show our preferred specifications. When the variable of interest is sector-specific, we control for country $\times$ year fixed effects; when it is country-specific, we include sector dummies. When focusing on interaction terms, both dimensions of fixed effects are included and the non-interacted variables are omitted. In section C.10 of the online appendix, we present additional, less demanding specifications in which some dimensions of fixed effects are omitted. The results reported there are similar to those obtained in the baseline specifications. We also show that the results are similar with more demanding specifications in which we include target sector $\times$ year fixed effects (section C.11).

Clustering. In section C.12 of the online appendix, we use alternative clustering strategies. We either allow the error term to be correlated within target industry or by target country $\times$ year. The overall picture is unaffected. Clustering at the industry level results in only 20 clusters. Simulations conducted by Cameron and Miller (forthcoming) suggest that, in general, having more clusters is better than having fewer clusters for obtaining appropriately sized tests.

Estimation. All of the results presented thus far assume that the empirical relations generated by the mechanisms outlined in the model are linear, which is a strong assumption given that the relations we estimate contain censored dependent variables. To verify that the empirical results are robust to this choice, we re-estimate the regressions predicting the share of full foreign acquisitions and the ownership stake regressions using fractional logit models. The estimates are provided in section C.13 of the online appendix. They show that the main conclusions remain unchanged when we use non-linear estimates.

\subsection{Domestic acquisitions and EU acquisitions}

The model applies to foreign acquisitions. The predictions arise because foreign firms are assumed to be less liquidity constraints than domestic ones. This implies that (i) our results should not hold for domestic acquisitions (e.g. Argentine firms acquiring other Argentine firms); (ii) our results should not hold (or at least not as strongly) for foreign acquisitions when the target and acquirer countries have similar level of financial development. In section C.14 we investigate (i) and show that most of the results lose significance when we consider the share acquired by domestic firms. While financial development and institutions alone still have a significant effect on the share of full acquisitions, both external finance dependence and its interactions with 
financial development or anti-corruption lose significance. Similarly, financial factors no longer have an effect on the share acquired among partial domestic acquisitions. These results are in line with our explanation that foreign firms are less financially constrained that domestic ones. In section C.15 we consider an alternative sample, drawn from the Zephyr dataset. The sample contains only foreign acquisitions taking place within the EU. The results are less robust than in our sample of emerging markets.

\section{Conclusion}

In this paper, we examine the choice of ownership structure in brownfield FDI projects. The analysis is motivated by the heterogeneity in foreign ownership across manufacturing industries in emerging market economies, which we document using a large dataset of cross-border M\&A transactions. While most recent research on FDI has focused on finance, local institutions, and technology separately, we use a model to show how these three factors act together to determine the degree of foreign ownership. A foreign acquirer can ease a target firm's credit constraint in a financially underdeveloped country, but it also faces a comparative disadvantage in providing local inputs for production due to weak institutions. A trade-off emerges between acquiring a larger stake in the target firm and incentivizing local input provision by domestic equity holders. The amount of foreign ownership that resolves this trade-off emerges as the solution of an optimal contracting problem between foreign and domestic agents. The ownership structure chosen thus balances the benefits and costs to foreign firms of operating in countries with low financial development and weak institutions.

We test the model's predictions using a dataset of cross-border M\&A in emerging markets supplemented with country- and sector-level data and find evidence consistent with them. All else equal, a firm that is more reliant on external finance, that is based in a country with a low level of financial development, or located in a country with stronger institutions is more likely to be fully acquired by a foreign firm. The sizes of foreign ownership stakes in partial acquisitions are insensitive to institutional factors and weakly dependent on financial factors. In addition, we validate the model's predictions regarding the relationship between financial and institutional factors and the likelihood of brownfield FDI across sectors and countries. External finance dependence magnifies the effects of financial underdevelopment and higher institutional quality. Taken together, this evidence shows that the interaction of financial, institutional, and technological factors plays an important role in determining the pattern of foreign ownership in North-South FDI flows.

\section{Acknowledgements}

We thank our discussants Anusha Chari, Črt Kostevc, Peter McQuade; Carlo Altomonte, Richard Baldwin, Eric Bond, Nicolas Coeurdacier, Kerem Coşar, Wei Cui, Ron Davies, Giovanni Facchini, Rex Ghosh, Sergei Guriev, Mathias Hoffmann, Nobu Kiyotaki, Ayhan Kose, Damien Neven, Ugo Panizza, Priya Ranjan, Assaf Razin, Cédric Tille, Farid Toubal, Lore Vandewalle, Vikrant Vig, Jiafu Wang, Stephen Yeaple; and participants at several seminars and conference for valuable comments and suggestions. We also thank Andrei Levchenko and 
Jing Zhang for sharing their cross-country sectoral productivity estimates. Michael Jenuwine, Alexandre Lauwers, Christian Proebsting, Dmitri Tchebotarev, Jingjing Xia and Jiafu Wang provided excellent research assistance at different points on this project. The project leading to this publication has received funding from Excellence Initiative of Aix-Marseille University - A*MIDEX, a French "Investissements d'Avenir" programme. Rahul Mukherjee acknowledges the support of the Swiss National Science Foundation (Research Grant No. 172690).

\section{References}

V.V. Acharya, H. Shin, and T. Yorulmazer. Fire-sale FDI. Korean Economic Review, 27(2): 163-202, 2011.

M. Aguiar and G. Gopinath. Fire-Sale Foreign Direct Investment and Liquidity Crises. Review of Economics and Statistics, 87:439-452, 2005.

Laura Alfaro, Paola Conconi, Harald Fadinger, and Andrew F Newman. Do prices determine vertical integration? The Review of Economic Studies, 83(3):855-888, 2016.

Laura Alfaro, Pol Antràs, Davin Chor, and Paola Conconi. Internalizing global value chains: A firm-level analysis. Journal of Political Economy, forthcoming.

Azizjon Alimov and Micah S Officer. Intellectual property rights and cross-border mergers and acquisitions. Journal of Corporate Finance, 2017.

Ron Alquist, Rahul Mukherjee, and Linda Tesar. Fire Sale FDI or Business as Usual? Journal of International Economics, 98:93-113, 2016.

Pol Antràs. Firms, Contracts, And Trade Structure. The Quarterly Journal of Economics, 118 (4):1375-1418, 2003.

Pol Antràs and Davin Chor. Organizing the global value chain. Econometrica, 81(6):2127-2204, 2013.

Pol Antràs and Elhanan Helpman. Global Sourcing. Journal of Political Economy, 112(3): $552-580,2004$.

Pol Antràs and Stephen Yeaple. Multinational firms and the structure of international trade. Handbook of International Economics, 4:55, 2014.

Pol Antràs, Mihir Desai, and C Fritz Foley. Multinational Firms, FDI Flows and Imperfect Capital Markets. Quarterly Journal of Economics, 124(3), 2009.

Jens Matthias Arnold and Beata S Javorcik. Gifted Kids or Pushy Parents? Foreign Direct Investment and Plant Productivity in Indonesia. Journal of International Economics, 79(1): $42-53,2009$.

Elizabeth Asiedu and Hadi Salehi Esfahani. Ownership Structure in Foreign Direct Investment Projects. Review of Economics and Statistics, 83(4):647-662, 2001. 
L. Kamran Bilir, David Chor, and Kalina Manova. Host-Country Financial Development and Multinational Activity. NBER Working Papers 20046, National Bureau of Economic Research, Inc, 2017. URL https://www.nber.org/papers/w20046.

Çagatay Bircan. Ownership structure and productivity of multinationals. Working Papers 203, EBRD, August 2017.

Garrick Blalock and Paul J Gertler. Welfare Gains from Foreign Direct Investment Through Technology Transfer to Local Suppliers. Journal of International Economics, 74(2):402-421, 2008 .

Stefano Bolatto, Alireza Naghavi, Gianmarco IP Ottaviano, and Katja Zajc. Intangible assets and the organization of global supply chains. University of Bologna Working Paper, (1105), 2017.

H. Bollaert and M. Delanghe. Securities Data Company and Zephyr, data sources for M\&A research. Journal of Corporate Finance, 33:85-100, 2015.

S Lael Brainard. An Empirical Assessment of the Proximity-Concentration Trade-Off Between Multinational Sales and Trade. American Economic Review, 87(4):520-544, 1997.

Arturo Bris and Christos Cabolis. The value of investor protection: Firm evidence from crossborder mergers. Review of Financial Studies, 21(2):605-648, 2008.

P. Bustos. FDI as a Source of Finance in Imperfect Capital Markets: Firm-Level Evidence from Argentina. mimeo, 2007.

A. C. Cameron and D. L. Miller. A Practioner's Guide to Cluster-Robust Inference. Journal of Human Resources, forthcoming.

A. Chari, P. P. Ouimet, and L. L. Tesar. The Value of Control in Emerging Markets. Review of Financial Studies, 23(4), 2010.

Pradeep K Chhibber and Sumit K Majumdar. Foreign ownership and profitability: Property rights, control, and the performance of firms in Indian industry. The Journal of Law and Economics, 42(1):209-238, 1999.

Han Ping Chor, Luke Davin, Pol Antras, Thibault Fally, and Russell Hillbery. Measuring the Upstreamness of Production and Trade Flows. American Economic Review Papers and Proceedings, 102(3):412-416, 2012.

Arnaud Costinot, Lindsay Oldenski, and James Rauch. Adaptation and the Boundary of Multinational Firms. Review of Economics and Statistics, 93(1):298-308, 2011.

Ronald Davies, Rodolphe Desbordes, and Anna Ray. Greenfield versus mergers and acquisitions fdi: Same wine, different bottles? Canadian Journal of Economics, forthcoming.

Rodolphe Desbordes and Shang-Jin Wei. The effects of financial development on foreign direct investment. Journal of Development Economics, 127:153-168, 2017. 
I. Erel, R. C. Liao, and M. S. Weisbach. Determinants of Cross-Border Mergers and Acquisitions. Journal of Finance, 67(3), 2012.

Isil Erel, Yeejin Jang, and Michael S Weisbach. Do Acquisitions Relieve Target Firms Financial Constraints? The Journal of Finance, 2014.

Mukesh Eswaran and Ashok Kotwal. A Theory of Contractual Structure in Agriculture. American Economic Review, 75, 1985.

Laurent Frésard, Ulrich Hege, and Gordon Phillips. Extending industry specialization through cross-border acquisitions. The Review of Financial Studies, 30(5):1539-1582, 2017.

Kenneth A Froot. Exchange Rates and Foreign Direct Investment: An Imperfect Capital Markets Approach. The Quarterly Journal of Economics, 1991.

David Greenaway, Alessandra Guariglia, and Zhihong Yu. The more the better? foreign ownership and corporate performance in china. The European Journal of Finance, 20(7-9):681-702, 2014.

International Country Risk Guide. Icrg indicator of quality of government. dataset (url), 2013.

Ann E. Harrison, Inessa Love, and Margaret S. McMillan. Global capital flows and financing constraints. Journal of Development Economics, 75(1):269-301, 2004.

Tomáš Havránek and Zuzana Iršová. Estimating vertical spillovers from fdi: Why results vary and what the true effect is. Journal of International Economics, 85(2):234-244, 2011.

Tomáš Havránek and Zuzana Iršová. Determinants of horizontal spillovers from fdi: Evidence from a large meta-analysis. World Development, 42:1-15, 2013.

Elhanan Helpman and Paul Krugman. Market Structure and Foreign Trade, 1985.

Elhanan Helpman, Marc J Melitz, and Stephen R Yeaple. Export Versus FDI with Heterogeneous Firms. American Economic Review, 94(1):300-316, 2004.

Yasheng Huang, Yue Ma, Zhi Yang, and Yifan Zhang. A Fire Sale without Fire: An Explanation of Labor-Intensive FDI in China. Journal of Comparative Economics, 44(4):884-901, 2016.

Beata S. Javorcik and Shang-Jin Wei. Corruption and Cross-Border Investment in Emerging Markets: Firm-Level Evidence. Journal of International Money and Finance, 28(4):605-624, 2009 .

Beata Smarzynska Javorcik and Mariana Spatareanu. To share or not to share: Does local participation matter for spillovers from foreign direct investment? Journal of Development Economics, 85(1):194-217, 2008.

Daniel Kaufmann, Aart Kraay, and Massimo Mastruzzi. Worldwide governance indicators. dataset (url), 2013.

Iris Kesternich and Monika Schnitzer. Who is Afraid of Political Risk? Multinational Firms and Their Choice of Capital Structure. Journal of International Economics, 82(2):208-218, 2010. 
Paul Krugman. The New Theories of International Trade and the Multinational Enterprise. The multinational corporation in the 1980s, pages 57-73, 1983.

Andrei A Levchenko and Jing Zhang. The Evolution of Comparative Advantage: Measurement and Welfare Implications. Journal of Monetary Economics, 78:96-111, 2016.

K. Manova, S.-J. Wei, and Z. Zhang. Firm Exports and Multinational Activity under Credit Constraints. Review of Economics and Statistics, 97(3):547-588, 2015.

James R Markusen. Multinationals, Multi-Plant Economies, and the Gains from Trade. Journal of international economics, 16(3):205-226, 1984.

T. Mayer. Market Potential and Development. CEPII Working Paper 2009-24, 2008.

S.B. Moeller, F.P. Schlingemann, and R.N. Stulz. Wealth Destruction on a Massive Scale? A Study of Acquiring-Firm Returns in the Recent Merger Wave. Journal of Finance, 60:757-782, 2005 .

Rahul Mukherjee and Christian Proebsting. Acquirers and Financial Constraints: Theory and Evidence from Emerging Markets. IHEID Working Paper, (21-2017), 2017.

Volker Nocke and Stephen Yeaple. Cross-Border Mergers and Acquisitions vs. Greenfield Foreign Direct Investment: The Role of Firm Heterogeneity. Journal of International Economics, 72 (2):336-365, 2007.

Volker Nocke and Stephen Yeaple. An Assignment Theory of Foreign Direct Investment. The Review of Economic Studies, 75(2):529-557, 2008.

Douglass C North. Institutions. Journal of economic perspectives, 5(1):97-112, 1991.

Nathan Nunn. Relationship-specificity, incomplete contracts and the pattern of trade. Quarterly Journal of Economics, 122(2):569-600, 2007.

Nathan Nunn and Daniel Trefler. Incomplete contracts and the boundaries of the multinational firm. Journal of Economic Behavior \&3 Organization, 94:330-344, 2013.

R.G. Rajan and L. Zingales. Financial Dependence and Growth. American Economic Review, 1998.

James E. Rauch. Networks versus markets in international trade. Journal of International Economics, 48(1):7-35, 1999.

Assaf Razin and Efraim Sadka. Corporate Transparency, Cream-Skimming and FDI. European Economic Review, 51(5):1263-1276, 2007.

Liugang Sheng and Dennis Tao Yang. Expanding Export Variety: The Role of Institutional Reforms in Developing Countries. Journal of Development Economics, 118(C):45-58, 2016.

Jan Svejnar and Stephen C Smith. The economics of joint ventures in less developed countries. The Quarterly Journal of Economics, 99(1):149-167, 1984. 
UNCTAD. World Investment Report, 2016. URL http://unctad.org/en/ PublicationsLibrary/wir2017_en.pdf.

J. Wang and X. Wang. Benefits of Foreign Ownership: Evidence from Foreign Direct Investment in China. Journal of International Economics, 97(2):325-338, 2015.

WBES. Obtaining Finance in Latin America and the Caribbean. Latin America and the Caribbean Series Note, (5), 2013. URL http://www.enterprisesurveys.org/ /media/ FPDKM/EnterpriseSurveys/Documents/Topic-Analysis/Obtaining-Finance-in-LAC . pdf.

Shang-Jin Wei. How taxing is corruption on international investors? Review of Economics and Statistics, 82:1-11, 2000.

Mahmut Yasar and Catherine J Morrison Paul. International Linkages and Productivity at the Plant Level: Foreign Direct Investment, Exports, Imports and Licensing. Journal of International Economics, 71(2):373-388, 2007. 